\title{
How to Build a Fast and Highly Sensitive Sound Detector That Remains Robust to Temperature Shifts
}

\author{
ํㅣㄹ Minghui Chen ${ }^{1}$ and ${ }^{-H e n r i q u e ~ v o n ~ G e r s d o r f f ~}{ }^{1,2}$ \\ ${ }^{1}$ Vollum Institute, and ${ }^{2}$ Oregon Hearing Research Center, Oregon Health \& Science University, Portland, Oregon 97239
}

Frogs must have sharp hearing abilities during the warm summer months to successfully find mating partners. This study aims to understand how frog hair cell ribbon-type synapses preserve both sensitivity and temporal precision during temperature changes. Under room $\left(\sim 24^{\circ} \mathrm{C}\right)$ and high $\left(\sim 32^{\circ} \mathrm{C}\right)$ temperature, we performed in vitro patch-clamp recordings of hair cells and their afferent fibers in amphibian papillae of either male or female bullfrogs. Afferent fibers exhibited a wide heterogeneity in membrane input resistance $\left(R_{\text {in }}\right)$ from $100 \mathrm{M} \Omega$ to $1000 \mathrm{M} \Omega$, which may contribute to variations in spike threshold and firing frequency. At higher temperatures, most fibers increased their frequency of spike firing due to an increase in spontaneous EPSC frequencies. Hair cell resting membrane potential $\left(\mathrm{V}_{\text {rest }}\right)$ remained surprisingly stable during temperature increases, because $\mathrm{Ca}^{2+}$ influx and $\mathrm{K}^{+}$outflux increased simultaneously. This increase in $\mathrm{Ca}^{2+}$ current likely enhanced spontaneous EPSC frequencies. These larger "leak currents" at $\mathrm{V}_{\text {rest }}$ also lowered $\mathrm{R}_{\text {in }}$ and produced higher electrical resonant frequencies. Lowering $\mathrm{R}_{\text {in }}$ will reduce the hair cells receptor potential and presumably moderate the systems sensitivity. Using membrane capacitance measurements, we suggest that hair cells can partially compensate for this reduced sensitivity by increasing exocytosis efficiency and the size of the readily releasable pool of synaptic vesicles. Furthermore, paired recordings of hair cells and their afferent fibers showed that synaptic delays shortened and multivesicular release becomes more synchronous at higher temperatures, which should improve temporal precision. Together, our results explain many previous in vivo observations on the temperature dependence of spikes in auditory nerves.

Key words: auditory nerve; $\mathrm{Ca}^{2+}$ current; EPSP; exocytosis; hair cell synapse; membrane resistance

\section{Significance Statement}

The vertebrate inner ear detects and transmits auditory information over a broad dynamic range of sound frequency and intensity. It achieves remarkable sensitivity to soft sounds and precise frequency selectivity. How does the ear of cold-blooded vertebrates maintain its performance level as temperature changes? More specifically, how does the hair cell to afferent fiber synapse in bullfrog amphibian papilla adjust to a wide range of physiological temperatures without losing its sensitivity and temporal fidelity to sound signals? This study uses in vitro experiments to reveal the biophysical mechanisms that explain many observations made from in vivo auditory nerve fiber recordings. We find that higher temperature facilitates vesicle exocytosis and electrical tuning to higher sound frequencies, which benefits sensitivity and selectivity.

\section{Introduction}

Bullfrogs that jump into a cold pond must adapt quickly to a sudden temperature shift. Indeed, frogs adapt to a wide range of physiological body temperatures (Lillywhite, 1970). In summer,

Received Sept. 26, 2018; revised June 13, 2019; accepted July 9, 2019.

Author contributions: M.C. and H.v.G. designed research; M.C. performed research; M.C. and H.v.G. analyzed data; M.C. wrote the first draft of the paper; M.C. and H.v.G. edited the paper; M.C. and H.v.G. wrote the paper

This work was supported by the National Institutes of Health, National Institute on Deafness and Other Communication Disorders Grant DC004274 to H.v.G. We thank Jutta Engel for conversations that inspired this study; Karina Leal, Geng-Lin Li, and Owen Gross for data analysis assistance; and Chad Grabner for very insightful discussions.

The authors declare no competing financial interests.

Correspondence should be addressed to Minghui Chen at chemi@ohsu.edu or Henrique von Gersdorff at vongersd@ohsu.edu.

https://doi.org/10.1523/JNEUROSCI.2510-18.2019

Copyright $\odot 2019$ the authors male frogs gather together and chorus to attract female frogs (Capranica, 1965). To successfully find mating partners, their hearing abilities must be sharp during the warm summer months. Bullfrog vocalization is composed of low- to mid-frequency sounds (200-2000 Hz) (Capranica, 1965; Smotherman and Narins, 2000; Simmons, 2004). In addition, hearing is also critical for hunting insects and for territorial behaviors (Emlen, 1968; Wiewandt, 1969). Insects flap their wings at frequencies ranging from $330 \mathrm{~Hz}$ (house flies) to $600 \mathrm{~Hz}$ (mosquitos), and can even reach $1040 \mathrm{~Hz}$ (small biting midges). All these sound frequencies are detected and transduced by one frog hearing organ, the amphibian papilla (van Dijk et al., 2011). Accordingly, recordings of spikes in bullfrog amphibian papilla auditory nerve fibers display tuning curves with greatest sensitivity and best frequencies (or 
lowest sound level thresholds) $\sim 500-650 \mathrm{~Hz}$ (Feng et al., 1975; Heffner and Heffner, 2007).

Hair cells transduce sound vibrations into graded electrical signals, which are then sent to the brain via all-or-none action potential (AP) spikes in the afferent fibers. At higher temperatures, in vivo single afferent fiber recordings have revealed an increase in spontaneous spike rates, a decrease in sound intensity threshold, a reduced latency of response to sound, and higher vector strength (or better phase-locking precision) (Stiebler and Narins, 1990; van Dijk et al., 1990). This indicates that the hearing organ of frogs transmit more sound information with higher sensitivity, shorter reaction times, and greater temporal precision at higher temperatures. What are the cellular and synaptic mechanisms that explain these in vivo observations?

Hair cells detect and transduce three aspects of sound: intensity, phase, and frequency. Information on the rapid onset and offset of sound transients must also be faithfully transmitted to the auditory nerves at ribbon-type synapses (Rutherford, 2015; Coate et al., 2019). Indeed, hair cells express ion channels with some of the fastest activation and deactivation kinetics (Engel, 2008; Heil and Peterson, 2017; Pangrsic et al., 2018). Sound signals are conveyed via transduction currents (I) mediated by $\mathrm{K}^{+}$ influx at the stereocilia bundles, resulting in graded receptor membrane potential $\left(\mathrm{V}_{\mathrm{m}}\right)$ changes. The detection of low-level sounds is facilitated if hair cells have a large input resistance $\left(\mathrm{R}_{\mathrm{in}}\right)$, given that $V_{m}=R_{i n} \times I$. However, phase-locking to higher frequency sounds with fine temporal precision requires shorter membrane time constants $\left(\tau_{\mathrm{m}}=\mathrm{R}_{\mathrm{in}} \times \mathrm{C}_{\mathrm{m}}\right.$, where $\mathrm{C}_{\mathrm{m}}$ is the hair cell membrane capacitance), which requires a small $R_{\text {in }}$. How does the hair cell cope with these conflicting demands on its biophysical properties? Does hair cell $\mathrm{R}_{\text {in }}$ decrease when temperature increases, as observed in other bullfrog neurons (Santin et al., 2013)? If so, how do auditory hair cells and their synapses compensate for temperature-dependent changes in $\mathrm{R}_{\text {in }}$ to maintain both sound sensitivity and temporal fidelity?

To answer these questions, we performed in vitro voltageclamp and current-clamp recordings from single hair cells and their afferent fibers in bullfrog amphibian papillae under both room $\left(23^{\circ} \mathrm{C}-25^{\circ} \mathrm{C}\right)$ and high $\left(30^{\circ} \mathrm{C}-33^{\circ} \mathrm{C}\right)$ temperature. Our results suggest that larger amplitudes and faster $\mathrm{Ca}^{2+}$ and $\mathrm{K}^{+}$current kinetics lead to higher hair cell intrinsic electrical resonance frequencies, whereas shorter synaptic delays, more synchronous multivesicular release, and decreased $R_{\text {in }}$ at high temperature contributes to more precise phase locking to sound signals. Moreover, we propose that hair cells compensate for lower $\mathrm{R}_{\text {in }}$ at high temperature by increasing the size of the readily releasable pool (RRP) of vesicles and the efficiency of exocytosis, resulting in an enhancement of sound sensitivity.

\section{Materials and Methods}

Animal care and tissue preparation. Adult bullfrogs (Rana catesbeiana; Rana Ranch) of both sexes were used for experiments. Protocols for animal care and anesthesia were approved by the Institutional Animal Care and Use Committee of Oregon Health and Science University. Bullfrogs were sedated in $7^{\circ} \mathrm{C}-10^{\circ} \mathrm{C}$ water bath for $\sim 5-10 \mathrm{~min}$, anesthetized by isoflurane $(0.025 \mathrm{ml} / \mathrm{g}$ body weight $)$ absorbed through the skin, and then double-pitched and decapitated. Amphibian papillae were carefully dissected, and the connection of hair cells and afferent fibers was exposed via a spit-open procedure as described previously (Keen and Hudspeth, 2006; Li et al., 2009).

Experimental design. The acutely split-open tissue preparation was placed in a recording chamber perfused with artificial perilymph containing the following (in $\mathrm{mm}$ ): $95 \mathrm{NaCl}, 2 \mathrm{KCl}, 2 \mathrm{CaCl}_{2}, 1 \mathrm{MgCl}_{2}, 25$ $\mathrm{NaHCO}_{3}, 3$ glucose, 1 creatine, and 1 sodium pyruvate, $\mathrm{pH} 7.30$ (osmo- larity $235 \mathrm{mOsm}$ ) at $1-2 \mathrm{ml} / \mathrm{min}$, bubbling with $95 \% \mathrm{O}_{2}$ and $5 \% \mathrm{CO}_{2}$. Reagents and salts were obtained from Sigma-Aldrich, if not specified otherwise. Temperature was adjusted by heating the bath perfusion with a temperature controller (Warner Instruments), which changed bath temperature between room $\left(23^{\circ} \mathrm{C}-25^{\circ} \mathrm{C}\right)$ and high $\left(30^{\circ} \mathrm{C}-33^{\circ} \mathrm{C}\right)$ temperatures. Tissue temperature was measured continuously by a miniature thermistor placed close to the perfused amphibian papillae preparation during patch-clamp recordings.

The semi-intact preparation of hair cells and their connecting afferent fibers was placed on an upright microscope with a $60 \times$ water-immersion objective (Olympus, BX51WI) and digital CCD camera (QImaging). Whole-cell patch recordings were performed with an EPC-10/2 (HEKA) patch-clamp amplifier controlled by PatchMaster software (HEKA). Recording pipettes were pulled on a PP-830 vertical puller (Narishige) from borosilicate glass pipettes (1B150F-4, World Precision Instruments). Patch pipettes were pulled to resistances of 5-7 $\mathrm{M} \Omega$ for hair cells. Pipettes were filled with the intracellular solution containing the following (in mM): 77 Cs-gluconate, $20 \mathrm{CsCl}, 1 \mathrm{MgCl}_{2}, 10$ TEA-Cl, 10 HEPES, 2 EGTA, $3 \mathrm{Mg}$-ATP, $1 \mathrm{Na}$-GTP, and $5 \mathrm{Na}_{2}$-phosphocreatine, adjusted to $\mathrm{pH} 7.3$ with $\mathrm{CsOH}$. We used 2 mM EGTA as the mobile internal $\mathrm{Ca}^{2+}$ buffer of hair cells (Frank et al., 2009; Johnson et al., 2017). The pH-independent $\mathrm{Ca}^{2+}$ buffer BAPTA (2 mM) and another pH buffer MOPS (10 mM) were also used in some experiments (see Fig. 9). To measure resting membrane potential (see Fig. $5 A$ ), outward potassium current (see Fig. $5 B, D$ ), membrane input resistance (see Fig. 6), and resonant frequency (see Fig. 7), we used a more physiological $\mathrm{K}^{+}$-based internal solution containing the following (in $\mathrm{mM}$ ): $77 \mathrm{~K}$-gluconate, $30 \mathrm{KCl}, 1 \mathrm{MgCl}_{2}, 10 \mathrm{HEPES}, 2$ EGTA, $3 \mathrm{Mg}$-ATP, $1 \mathrm{Na}$-GTP, and $5 \mathrm{Na}_{2}$-phosphocreatine, adjusted to $\mathrm{pH} 7.3$ with $\mathrm{KOH}$. To preserve a more intact hair cell intracellular milieu, we also performed perforated-patch recordings using an internal solution with gramicidin $(40-50 \mu \mathrm{g} / \mathrm{ml}$; see Figs. $5 A, 6)$ plus a fluorescent dye (AlexaFluor-488 Hydrazide; Thermo Fisher Scientific). Hair cells containing dye in their cytoplasm were excluded from analysis.

In voltage clamp, hair cells were held at a membrane potential of -90 $\mathrm{mV}$. Membrane potentials were corrected for a liquid junction potential of $10 \mathrm{mV}$. In current clamp, hair cells were held at zero current. Wholecell calcium currents $\left(\mathrm{I}_{\mathrm{Ca}}\right)$ were leak-subtracted using a $\mathrm{P} / 4$ protocol. The uncompensated series resistances $\left(\mathrm{R}_{\mathrm{s}}\right)$ in whole-cell recordings were $10.5 \pm 0.4 \mathrm{M} \Omega$ for hair cells $(n=36)$. The uncompensated average $\mathrm{R}_{\mathrm{s}}$ in perforated-patch recordings was $40.1 \pm 1.3 \mathrm{M} \Omega(n=9)$.

We used membrane capacitance $\left(\mathrm{C}_{\mathrm{m}}\right)$ measurements to monitor exocytosis (vesicle fusion). Patch pipettes were coated with dental wax to minimize their stray capacitance. The $\mathrm{C}_{\mathrm{m}}$ from hair cells was measured under whole-cell voltage-clamp conditions using the "Sine + DC" method (Lindau and Neher, 1988; Moser and Beutner, 2000). A 2 kHz sinusoidal command voltage of $50 \mathrm{mV}$ peak-to-peak magnitude was superposed on the hair cell holding potential of $-90 \mathrm{mV}$. The resulting current response was used to calculate $C_{m}$ via a software emulator of a lock-in amplifier (Gillis, 2000). The increase of $\mathrm{C}_{\mathrm{m}}\left(\Delta \mathrm{C}_{\mathrm{m}}\right)$ evoked by membrane depolarization was measured as $\Delta \mathrm{C}_{\mathrm{m}}=\mathrm{C}_{\mathrm{m} \text { (response) }}-\mathrm{C}_{\mathrm{m} \text { (resting) }}$. Here $\mathrm{C}_{\mathrm{m} \text { (resting) }}$ and $\mathrm{C}_{\mathrm{m} \text { (response) }}$ were obtained by averaging capacitance data points before and after the depolarizing steps using Igor Pro 6.0 (WaveMetrics) software. We excluded recordings in which the uncompensated series resistance was $>15 \mathrm{M} \Omega$ or the holding current was $>100$ $\mathrm{pA}$. The thin steriocelia of hair cells may not be under full space clamp, so their contribution to resting $\mathrm{C}_{\mathrm{m}}$ may be underestimated (Breneman et al., 2009).

Afferent fibers were patched with $8-10 \mathrm{M} \Omega$ patch pipette filled with the $\mathrm{K}^{+}$-based internal solution, as described above. Membrane potentials were corrected for a liquid junction potential of $10 \mathrm{mV}$. Spontaneous EPSCs were recorded from the voltage-clamped afferent fibers held at $-90 \mathrm{mV}$. Spontaneous EPSPs were recorded in current-clamp mode from afferent fibers with zero current injection. The uncompensated $R_{s}$ in whole-cell recordings of afferent fibers was $27.9 \pm 3.2 \mathrm{M} \Omega(n=8)$. An excessively high series resistance can reduce and filter large EPSC events because of significant voltage-clamp errors (Li et al., 2009). Therefore, we excluded afferent fibers with uncompensated series resistance $>50 \mathrm{M} \Omega$ from analysis, and we electronically compensated afferent fiber whole- 
A1 $23^{\circ} \mathrm{C} \quad$ High spontaneous spiking fibers $(71 \%)$

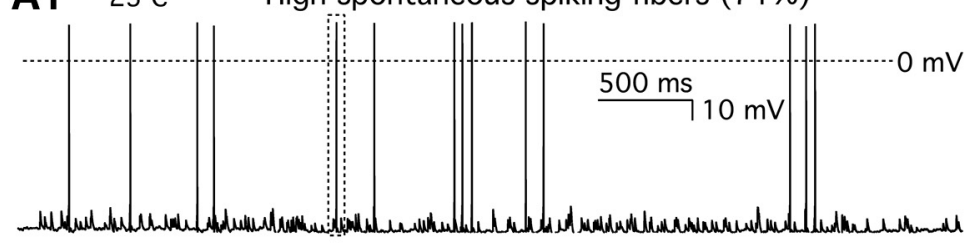

A3
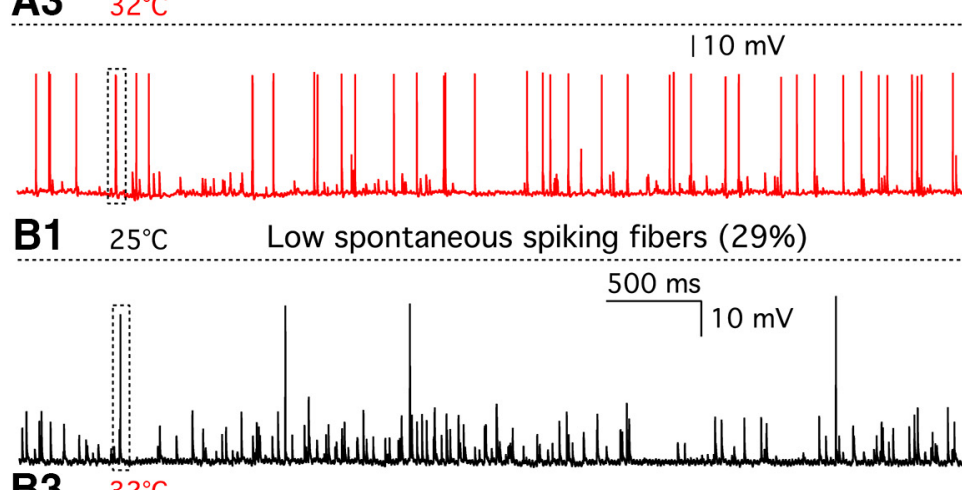

B3

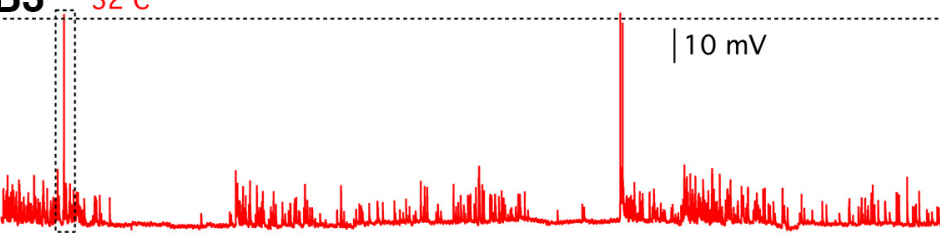

A2

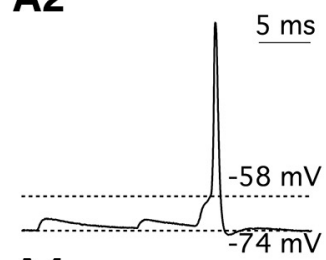

A4

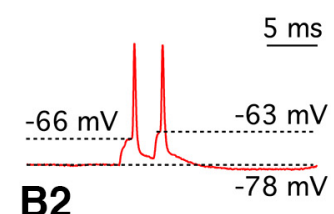

B2

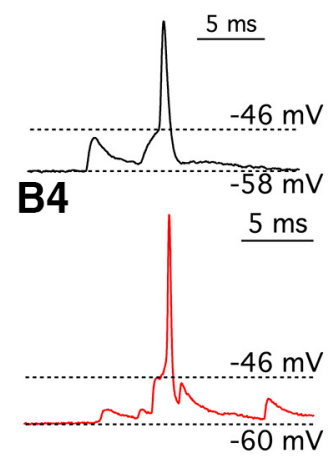

Figure 1. Heterogeneity in the temperature dependence of afferent fiber spikes. $\boldsymbol{A} 1$, Whole-cell current-clamp recordings of afferent fiber with zero current injection at $23^{\circ} \mathrm{C}$. AP spikes and EPSPs can be clearly distinguished. Dashed line indicates $0 \mathrm{mV}$. $\mathbf{A 2}$, The spike shown in a dashed line box in $\boldsymbol{A} \mathbf{1}$ was expanded in time scale. Resting membrane potential $\left(\mathrm{V}_{\text {rest }}\right)$ was $-74 \mathrm{mV}$, and $\mathrm{AP}$ threshold was $-58 \mathrm{mV}$. $\boldsymbol{A}$, Spontaneous spikes from the same afferent fiber shown in $\boldsymbol{A} \mathbf{1}$ were recorded at $32^{\circ} \mathrm{C}$. $\boldsymbol{A}$, Spikes shown in a dashed line box in $\boldsymbol{A} \boldsymbol{3}$ are expanded in time scale. $V_{\text {rest }}$ was $-78 \mathrm{mV}$. Thresholds of the first and the second AP were -66 and $-63 \mathrm{mV}$, respectively. Five of seven afferent fibers (71\%) fired more spikes at high temperature. B1, Spontaneous spikes were recorded from another afferent fiber at $25^{\circ} \mathrm{C}$. Dashed line indicates $0 \mathrm{mV}$. B2, The spike shown in a dashed line box in $B 1$ was expanded in time scale. $V_{\text {rest }}$ was $-58 \mathrm{mV}$, and AP threshold was -46 $\mathrm{mV} . \mathbf{B 3}$, Spontaneous spikes from the same fiber shown in $\boldsymbol{B} 1$ were recorded at $32^{\circ} \mathrm{C} . \boldsymbol{B} 4$, The spike shown in a dashed line box in $B 3$ was expanded in time scale. $V_{\text {rest }}$ was $-60 \mathrm{mV}$, and $A P$ threshold was $-46 \mathrm{mV}$. Two of seven afferent fibers (29\%) fired less spikes at high temperature.

cell recordings up to $35 \%$ depending on the uncompensated series resistance to maintain a constant series resistance throughout the recordings.

Statistical analysis. Statistical analysis was performed using Prism 6 (GraphPad Software) and Excel (Microsoft). Results are presented as mean \pm SEM ( $n=$ number of cells). If not specified, statistical significance was determined using paired Student's $t$ test. We chose $p<0.05$ to be the criterion for statistical significance.

Data analyses and curve fitting were performed using Igor Pro 6.0. The threshold of an AP was defined as membrane potential $\left(\mathrm{V}_{\mathrm{m}}\right)$ when the slope of $\mathrm{V}_{\mathrm{m}}$ versus time started to increase compared with that of preceding EPSP. Our estimation was consistent with the threshold estimated by phase plots, which plot membrane potential slope $\left(\mathrm{dV}_{\mathrm{m}} / \mathrm{dt}\right)$ versus $\mathrm{V}_{\mathrm{m}}$ (Yang et al., 2016). Biophysical properties of spontaneous EPSCs and EPSPs (i.e., amplitude, frequency, rise time, and $\tau_{\text {decay }}$ ) were analyzed using a customized protocol written by Dr. Owen Gross. The rise time was calculated as the interval between $10 \%$ and $90 \%$ of the peak amplitude relative to baseline. The $\tau_{\text {decay }}$ of averaged EPSCs or EPSPs was estimated by a single exponential fit using the equation:

$$
I(t)=A \exp (-t / \tau)+I_{s s}
$$

where $I(t)$ is the current as a function of time, $A$ is the amplitude at time $0, \tau$ is the time constant, and $I_{s s}$ is the steady-state current amplitude. The temperature coefficient $\left(\mathrm{Q}_{10}\right)$ is the coefficient by which a quantity increases after a change of $10^{\circ} \mathrm{C} . \mathrm{Q}_{10}$ values for amplitude, frequency, rise time, and time constant of decay as well as $\Delta \mathrm{C}_{\mathrm{m}}$ were calculated using the following equation:

$$
Q_{10}=\left(F_{H} / F_{L}\right)^{10 / \Delta T}
$$

where $F_{L}$ and $F_{H}$ are factors of interest measured at room $\left(23^{\circ} \mathrm{C}-25^{\circ} \mathrm{C}\right)$ and high $\left(30^{\circ} \mathrm{C}-33^{\circ} \mathrm{C}\right)$ temperature, respectively, and $\Delta \mathrm{T}$ is the absolute value of the temperature difference.

\section{Results}

Most afferent fibers fire more spikes at higher temperature

To determine the temperature dependence of spontaneous spikes at hair cell afferent fibers, we recorded spontaneous potential changes in afferent fibers using whole-cell current clamp with zero current injection. At $23.7 \pm 0.2^{\circ} \mathrm{C}$, the frequency of spikes was $2.0 \pm 0.64 \mathrm{~Hz}$, amplitude was $51.9 \pm 6.8 \mathrm{mV}$, threshold was $-51.0 \pm 2.0 \mathrm{mV}$, and resting membrane potential $\left(\mathrm{V}_{\text {rest }}\right)$ of afferent fibers was $-66.9 \pm 2.1 \mathrm{mV}(n=18)$. Among these fibers, seven of them displayed big spikes that overshot $0 \mathrm{mV}$ with higher threshold (Fig. 1A1). The amplitude of these big spikes was $85.7 \pm 5.7 \mathrm{mV}(n=6)$, whereas the amplitude of spikes that did not overshoot was $35.0 \pm 4.8 \mathrm{mV}(n=12, p<0.0001)$. The threshold of the big spikes was $-44.1 \pm 2.4 \mathrm{mV}(n=6)$, whereas the threshold of small spikes was $-54.8 \pm 2.1 \mathrm{mV}(n=12, p=$ 0.0063 , unpaired $t$ test). There was no statistical difference between these two groups in frequency (overshooting: $2.02 \pm 0.56$ Hz vs nonovershooting: $1.99 \pm 0.94 \mathrm{~Hz}, p=0.98$, unpaired $t$ test) and $\mathrm{V}_{\text {rest }}$ (overshooting: $-64.1 \pm 4.6 \mathrm{mV}$ vs nonovershooting: $-68.3 \pm 2.3 \mathrm{mV}, p=0.37)$.

For 7 of these 18 fibers, we successfully recorded spikes at both room and high temperature. Five of them fired more spikes at 
Table 1. Temperature dependence of afferent fiber spikes

\begin{tabular}{lccll}
\hline Thermal positive fiber $(n=5)$ & $23.7 \pm 0.5^{\circ} \mathrm{C}$ & $31.1 \pm 0.4^{\circ} \mathrm{C}$ & $p$ & $Q_{10}$ \\
\hline Frequency $(\mathrm{Hz})$ & $4.4 \pm 1.9$ & $9.4 \pm 3.5$ & 0.047 & $4.0 \pm 1.2$ \\
Amplitude $(\mathrm{mV})$ & $75.7 \pm 16.0$ & $44.8 \pm 11.1$ & 0.075 & $0.6 \pm 0.1$ \\
Threshold $(\mathrm{mV})$ & $-53.9 \pm 4.3$ & $-58.6 \pm 4.0$ & 0.016 & $1.1 \pm 0.03$ \\
Resting potential $(\mathrm{mV})$ & $-70.1 \pm 3.7$ & $-70.7 \pm 3.4$ & 0.55 & $1.0 \pm 0.02$ \\
\hline Thermal negative fiber $(n=2)$ & $24.2 \pm 0.3^{\circ} \mathrm{C}$ & $31.7 \pm 0.4^{\circ} \mathrm{C}$ & \\
\hline Frequency (Hz) & $0.7 \pm 0.1$ & $0.3 \pm 0.2$ & & \\
Amplitude $(\mathrm{mV})$ & $46.8 \pm 3.1$ & $47.6 \pm 8.4$ & & \\
Threshold $(\mathrm{mV})$ & $-48.6 \pm 3.1$ & $-43.4 \pm 4.5$ & & \\
Resting potential $(\mathrm{mV})$ & $-66.1 \pm 8.0$ & $-65.1 \pm 5.9$ & & \\
\hline
\end{tabular}

Values are mean \pm SEM.

high temperature (Table 1; Fig. 1A1-A4). We called these fibers "thermal-positive fibers." The temperature coefficient $\left(\mathrm{Q}_{10}\right)$ of spontaneous spiking rate was $4.0 \pm 1.2(n=5)$, which was similar to that found in rat fibers (median $\mathrm{Q}_{10}=6.6$ ) (Wu et al., 2016). Although threshold for firing an AP at high temperature (-58.6 $\mathrm{mV})$ was lower than that at room temperature $(-53.9 \mathrm{mV}, n=5$, $p=0.0158)$, spike probability rates remain the same throughout temperature change: at room temperature, $25.8 \%$ of EPSPs evoked a spike; and at high temperature, $25.4 \%$ of EPSPs evoked a spike $(n=5, p=0.97)$. A decrease in afferent fiber membrane input resistance at high temperature results in faster EPSP decay (see Fig. 4), making it more difficult for them to summate, which counteracts the potential increase in spike probability caused by lower thresholds. By contrast, in mammalian cochlear spiral ganglion neurons, $80 \%-97 \%$ of EPSPs evoke a spike under room temperature (Rutherford et al., 2012). The low spike failure rate of EPSPs in mammalian fibers may result from the smaller surface area and high input resistance of the mammalian postsynaptic bouton (Rutherford et al., 2012). In bullfrog amphibian papilla, each hair cell connects with 3-6 large claw-like afferent fiber endings and each fiber receives multiple ribbon synapses (Graydon et al., 2014), while each mammalian afferent fiber only connects with just one single synaptic ribbon (Liberman, 1980; Rutherford, 2015).

The other two fibers fired less spikes at high temperature (Table 1; Fig. 1B1-B4), and we called these "thermal-negative fibers." The thermal-negative fibers had low spontaneous spiking rate $(<1 \mathrm{~Hz}$; Table 1$)$. In rat auditory nerve, spontaneous spiking rate increases during maturation of the cochlear from $3.87 \mathrm{~Hz}$ at P15-P17 to $12.85 \mathrm{~Hz}$ at P29-P32 (Wu et al., 2016). It is possible that some low-frequency spiking fibers in the frog may receive synaptic release from some immature hair cells at the edge of the amphibian papilla (Lewis and Li, 1975).

\section{Frequencies of spontaneous EPSCs and EPSPs are enhanced at high temperature}

To examine how temperature affects hair cell spontaneous release, we recorded spontaneous EPSCs from afferent fibers without voltage-clamping their presynaptic hair cells under room (black traces) and high (red traces) temperature (Fig. 2A1,B1). The frequency of the EPSCs increased from $78.2 \pm 9.5 \mathrm{~Hz}$ at room temperature to $115.2 \pm 9.7 \mathrm{~Hz}$ at high temperature $(n=18$, $p=0.0097$; Table 2). The EPSC amplitude distribution of an afferent fiber in Figure $2 A 2$ also shows that more EPSCs occurred under high temperature. The EPSC amplitude distribution was fit well with a Gaussian function (Fig. $2 A 2: R^{2}=0.96$ at $22^{\circ} \mathrm{C} ; R^{2}$ $=0.93$ at $32^{\circ} \mathrm{C}$ ). The peaks of Gaussian fits fell at $93.5 \mathrm{pA}$ at $22^{\circ} \mathrm{C}$ and at $89.7 \mathrm{pA}$ at $32^{\circ} \mathrm{C}$ (Fig. 2A2), suggesting that the average EPSC amplitude did not increase at high temperature. Most af- ferent fibers (12 of 18) did not show an increase in EPSC amplitude at high temperature, and the average of EPSC amplitude remained the same as temperature changed ( $p=0.61$; Table 2$)$. In Figure 2A3, average EPSCs were normalized to their peak values, and a single exponential function was used to fit the decay phase of EPSCs and determine the time constant of decay $\left(\tau_{\text {decay }}\right)$. The $10 \%-90 \%$ rise time and $\tau_{\text {decay }}$ of EPSCs were $223 \pm 13 \mu$ s and $617 \pm 36 \mu \mathrm{s}(n=18$; Table 2$)$ at room temperature, which are faster than that measured in immature rat afferent fibers (Yi et al., 2010) but similar to that measured in the afferent fibers of adult turtle (Schnee et al., 2013) and hearing rats (Grant et al., 2010). Elevating temperature decreased both $10 \%-90 \%$ rise time and $\tau_{\text {decay }}$ of EPSCs with $\mathrm{Q}_{10}$ values of 1.7 and 1.8, respectively (Table 2 ). This is consistent with our previous findings showing that decreasing temperature from $25^{\circ} \mathrm{C}$ to $15^{\circ} \mathrm{C}$ slows down activation and decay of EPSCs in bullfrog afferent fibers (Li et al., 2009). Similarly, in rat AII amacrine cells, increasing temperature from $26^{\circ} \mathrm{C}$ to $34^{\circ} \mathrm{C}$ decreases both rise time and $\tau_{\text {decay }}$ of mEPSCs with $\mathrm{Q}_{10}$ values of 1.3 and 1.5, respectively (Veruki et al., 2003). Calculating the integrals of EPSCs, we found that the postsynaptic charge transfer was decreased at high temperature (Table 2), which may be due to faster activation and deactivation (Fig. $2 A 3, B 3)$ of postsynaptic AMPA receptors and faster glutamate transporter activity at high temperature (Auger and Attwell, 2000).

Among all the afferent fibers recorded, 5 of 18 (28\%) exhibited double peaks in the EPSC amplitude distribution at both room and high temperatures. Figure $2 B 1$ shows EPSCs recorded from an afferent fiber that had a double-peak distribution (Fig. 2B2). Double- or triple-peak EPSC amplitude distributions have been observed previously in afferent fibers of mature rats (Grant et al., 2010) and turtle (Schnee et al., 2013). We divided EPSCs into two groups according to their amplitude: small EPSCs with amplitude $<150 \mathrm{pA}$ and large EPSCs with amplitude $>150 \mathrm{pA}$. The frequency distributions of EPSC amplitude in each group were fit well with a Gaussian function (small events: $R^{2}=0.94$ at $23^{\circ} \mathrm{C}, R^{2}=0.93$ at $31^{\circ} \mathrm{C}$; large events: $R^{2}=0.93$ at $23^{\circ} \mathrm{C}, R^{2}=$ 0.97 at $31^{\circ} \mathrm{C}$ ). Under $23^{\circ} \mathrm{C}$, the first and the second peak of the Gaussian fits were 78 and $292 \mathrm{pA}$, respectively. Under $31^{\circ} \mathrm{C}$, the first and the second peak were 89 and $279 \mathrm{pA}$, respectively. Under $23^{\circ} \mathrm{C}$, there were $65 \%$ of EPSCs $>150 \mathrm{pA}$. The group of large EPSCs increased to $74 \%$ at $31^{\circ} \mathrm{C}$.

Spontaneous EPSPs were also recorded from afferent fibers using whole-cell current clamp with 0 pA holding current. Consistent with EPSCs, the frequency of EPSPs increased from 40.4 $\mathrm{Hz}$ at $23.4^{\circ} \mathrm{C}$ to $56.9 \mathrm{~Hz}$ at $31.5^{\circ} \mathrm{C}(n=19, p=0.003$; Table 2). However, the response of EPSP amplitudes was variable: 58\% (11 of 19) of the fibers showed a reduced average EPSP amplitude at high temperature. This could be caused by a strong activation of $\mathrm{K}^{+}$currents in the afferents that blunts the EPSP amplitude at higher temperatures. However, averaging the entire dataset revealed no statistical difference in the amplitude of EPSPs between room and high temperature $(3.9 \pm 0.3 \mathrm{mV}$ vs $3.8 \pm 0.4 \mathrm{mV}$, respectively; $n=19, p=0.8$; Table 2 ).

Figure $3 A$ shows one example with decreased EPSP amplitude at high temperature, and Figure $3 B$ shows another example with increased EPSP amplitude at high temperatures. The EPSP amplitude distribution is shown in Figure 3A2, where 1250 and 1817 EPSPs events were counted from an afferent fiber at $23^{\circ} \mathrm{C}$ and $31^{\circ} \mathrm{C}$, respectively. The amplitude distributions of EPSPs were fit well with a Gaussian function (Fig. $3 A 2: R^{2}=0.89$ at $23^{\circ} \mathrm{C} ; R^{2}=$ 0.97 at $31^{\circ} \mathrm{C}$ ). The peaks of the Gaussian fit are $5.7 \mathrm{mV}$ at $23^{\circ} \mathrm{C}$ and $2.7 \mathrm{mV}$ at $31^{\circ} \mathrm{C}$. The single-exponential fit to the decay phase 

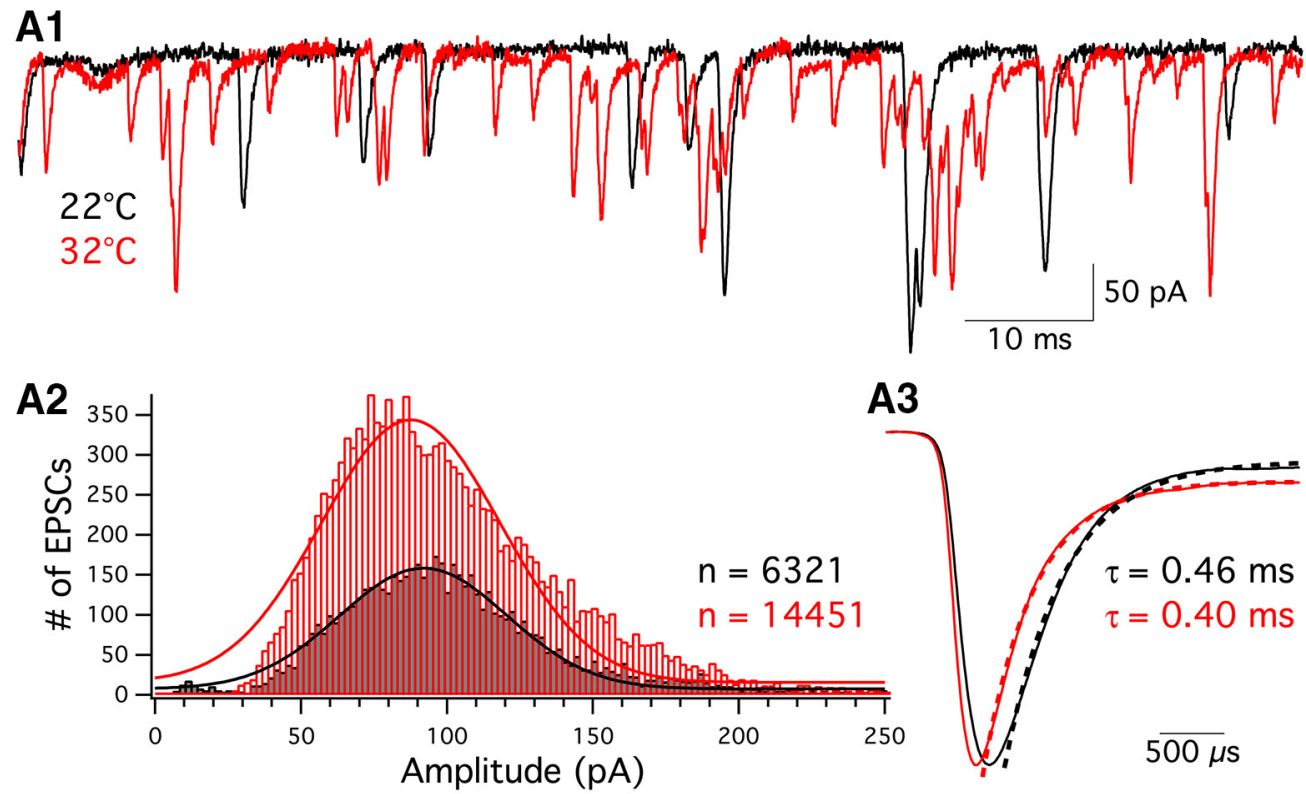

A3
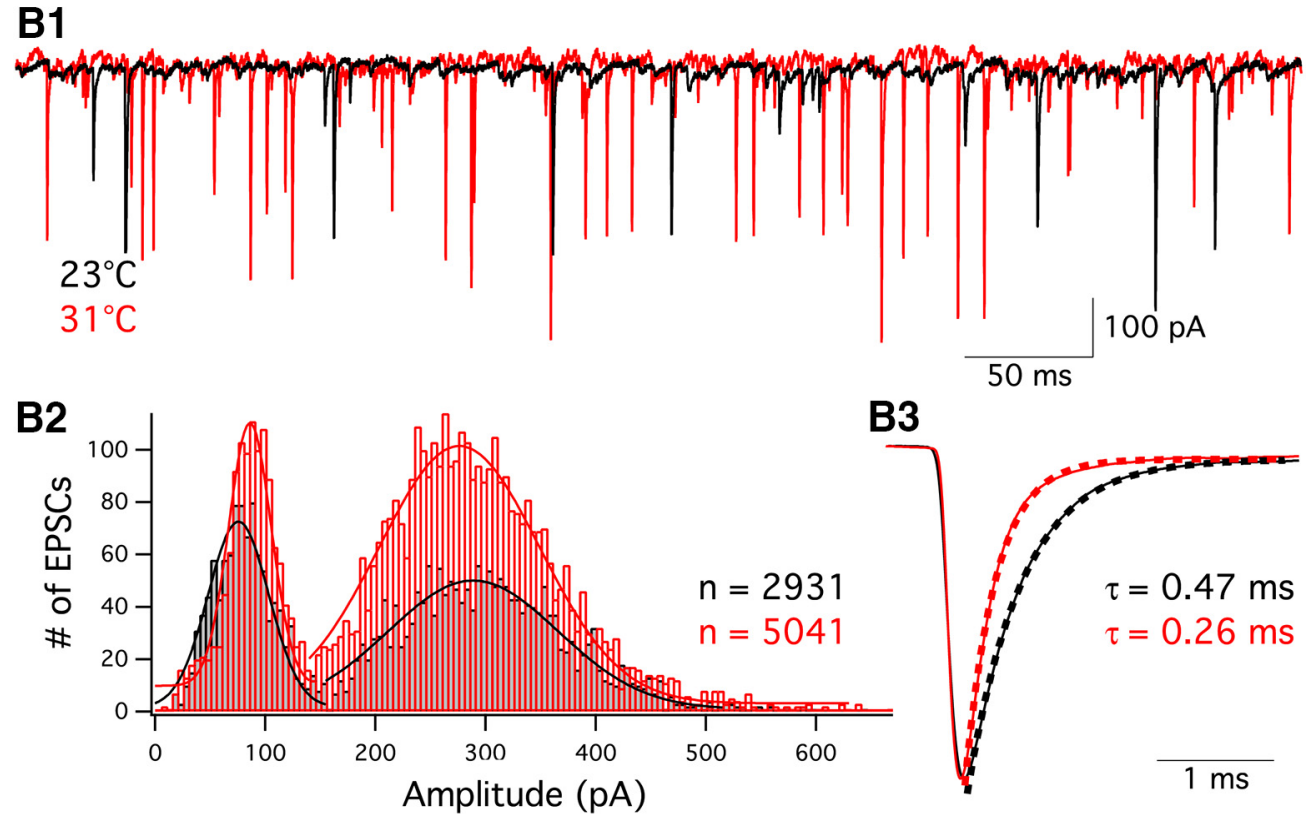

B3

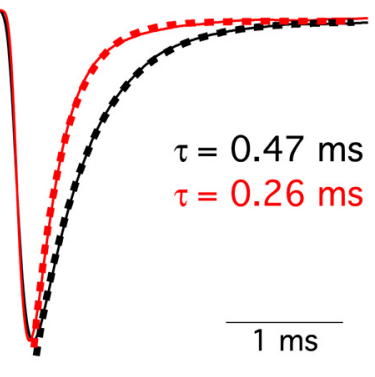

Figure 2. Spontaneous EPSC frequency increases at high temperature. $\boldsymbol{A 1}$, EPSCs were recorded from an afferent fiber, which was voltage-clamped at $-90 \mathrm{mV}$ at $22^{\circ} \mathrm{C}(\mathrm{black})$ and $32^{\circ} \mathrm{C}(\mathrm{red})$. $\boldsymbol{A 2}$, A total of 6321 and $14451 \mathrm{EPSC}$ were obtained at $22^{\circ} \mathrm{C}$ (black) and $32^{\circ} \mathrm{C}$ (red), respectively. EPSC amplitude distributions were fit with a Gaussian function. $A 3$, Average of EPSCs recorded at $22^{\circ} \mathrm{C}$ (black) and $32^{\circ} \mathrm{C}\left(\right.$ red) were normalized to their peak value. Single-exponential fits to the decay phase of averaged EPSCs showed that $\tau_{\text {decay }}$ was $0.46 \mathrm{~ms} \mathrm{at} 22^{\circ} \mathrm{C}$ (black dashed line) and $0.40 \mathrm{~ms} \mathrm{at}$ $32^{\circ} \mathrm{C}$ (red dashed line), respectively. B1, EPSCs were recorded from another afferent fiber at $23^{\circ} \mathrm{C}$ (black) and $31^{\circ} \mathrm{C}$ (red). B2, A total of 2931 and $5041 \mathrm{EPSCs}$ were obtained at $23^{\circ} \mathrm{C}$ (black) and $31^{\circ} \mathrm{C}$ (red), respectively. Two peaks are present on the amplitude distribution. EPSCs were divided into two groups according to their size: small EPSCs with amplitude $<150 \mathrm{pA}$ and large EPSCs with amplitude $>150 \mathrm{pA}$. The EPSC amplitude distributions in each group were fit with a Gaussian function. B3, Average of EPSCs recorded at $23^{\circ} \mathrm{C}$ (black) and $31^{\circ} \mathrm{C}$ (red) were normalized to their peak value. Single-exponential fits to the decay phase of averaged EPSCs showed that $\tau_{\text {decay }}$ was $0.47 \mathrm{~ms}$ at $24^{\circ} \mathrm{C}$ (black dashed line) and $0.26 \mathrm{~ms}$ at $31^{\circ} \mathrm{C}$ (red dashed line), respectively.

Table 2. Biophysical properties of afferent fiber EPSCs and EPSPs

\begin{tabular}{lcccc}
\hline $\operatorname{EPSC}(n=18)$ & $23.4 \pm 0.1^{\circ} \mathrm{C}$ & $31.1 \pm 0.1^{\circ} \mathrm{C}$ & $p$ & $Q_{10}$ \\
\hline Amplitude $(\mathrm{pA})$ & $80.5 \pm 6.8$ & $77.7 \pm 7.4$ & 0.61 & $1.1 \pm 0.2$ \\
Frequency $(\mathrm{Hz})$ & $78.2 \pm 9.5$ & $115.2 \pm 9.7$ & 0.0097 & $3.2 \pm 1.1$ \\
Rise time $(\mu \mathrm{s})$ & $223 \pm 13$ & $150 \pm 6$ & $<0.0001$ & $1.7 \pm 0.1$ \\
$\tau_{\text {decay }}(\mu \mathrm{s})$ & $617 \pm 36$ & $400 \pm 24$ & $<0.0001$ & $1.8 \pm 0.1$ \\
Charge transfer (fC) & $-71.3 \pm 5.2$ & $-47.9 \pm 3.4$ & $<0.0001$ & \\
\hline EPSP $(n=19)$ & $23.4 \pm 0.1^{\circ} \mathrm{C}$ & $31.5 \pm 0.1^{\circ} \mathrm{C}$ & $p$ & $Q_{10}$ \\
\hline Amplitude $(\mathrm{mV})$ & $3.9 \pm 0.3$ & $3.8 \pm 0.4$ & 0.8 & $1.1 \pm 0.2$ \\
Frequency $(\mathrm{Hz})$ & $40.4 \pm 6.1$ & $56.9 \pm 7.0$ & 0.003 & $2.1 \pm 0.5$ \\
$\tau_{\text {decay }}$ (ms) & $3.50 \pm 0.69$ & $1.67 \pm 0.38$ & $<0.0001$ & $2.7 \pm 0.4$ \\
\hline
\end{tabular}

Values are mean \pm SEM. of averaged EPSPs (Fig. 3A3) showed that $\tau_{\text {decay }}$ was $2.7 \pm 0.4 \mathrm{~ms}$ at room temperature $(n=19$; Table 2$)$. This is faster than that found in afferent fibers of immature rat (Yi et al., 2010). EPSPs shown in Figure 3B1 were recorded from the same afferent fiber with double-peak EPSC amplitude distribution as shown in Figure 2B2. During 30-s-long recordings, 1054 and 1581 EPSPs were recorded from another afferent fiber under room and high temperature, respectively (Fig. 3B2). The frequency distribution of EPSP amplitudes shown in Figure $3 B 2$ also had double peaks at high temperature, but not under room temperature. Under $23^{\circ} \mathrm{C}$, the peak of the Gaussian fit was $2.7 \mathrm{mV}\left(R^{2}=0.87\right)$. Under $31^{\circ} \mathrm{C}$, the first and the second peak were $3.4 \mathrm{mV}\left(R^{2}=0.85\right)$ and $7.3 \mathrm{mV}$ 

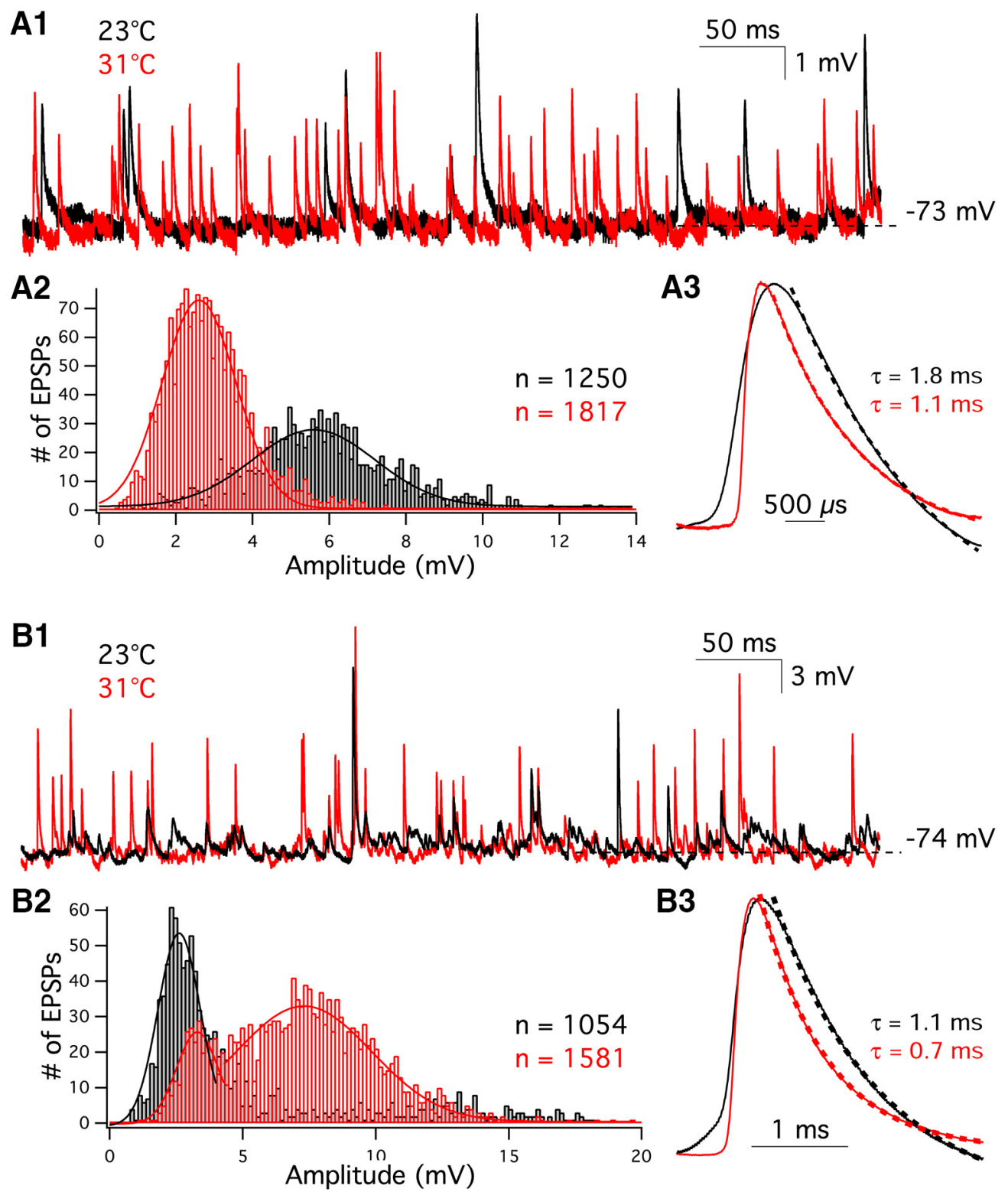

Figure 3. Spontaneous EPSPs are faster, and their frequency increases at high temperature. $\boldsymbol{A 1}$, EPSPs were recorded from an afferent fiber at $23^{\circ} \mathrm{C}\left(\right.$ black) and $31^{\circ} \mathrm{C}($ red). The membrane current of fiber was clamped at $0 \mathrm{pA}$. $\mathbf{A 2}$, A total of 1250 and 1817 EPSPs were recorded at $23^{\circ} \mathrm{C}$ (black) and $31^{\circ} \mathrm{C}($ red), respectively. The EPSP amplitude distributions were fit with a Gaussian function. $A 3$, Average EPSPs recorded at $23^{\circ} \mathrm{C}$ (black solid line) and $31^{\circ} \mathrm{C}$ (red solid line) were normalized to their peak values. Dashed lines are single-exponential fits to the decay phase of the average EPSPs. In this example, $\tau_{\text {decay }}$ was $1.8 \mathrm{~ms}$ at $23^{\circ} \mathrm{C}$ (black dashed line) and $1.1 \mathrm{~ms}$ at $31^{\circ} \mathrm{C}$ (red dashed line), respectively. B1, EPSPs were recorded from the same afferent fiber as shown in Figure $2 B 1-B 3$, at $23^{\circ} \mathrm{C}$ (black) and $31^{\circ} \mathrm{C}$ (red). B2, A total of 1054 and 1581 EPSPs were recorded under room and high temperature. B3, Average of EPSPs recorded at $23^{\circ} \mathrm{C}\left(\right.$ black) and $31^{\circ} \mathrm{C}($ red) were normalized to their peak values. Single-exponential fits to the decay phase of averaged EPSPs (dashed lines) revealed that $\tau_{\text {decay }}$ was $1.1 \mathrm{~ms}$ at $23^{\circ} \mathrm{C}$ and $0.7 \mathrm{~ms}$ at $31^{\circ} \mathrm{C}$, respectively.

$\left(R^{2}=0.81\right)$, respectively. In addition, the $\mathrm{V}_{\text {rest }}$ of the afferent fiber was slightly depolarized from $-74.0 \pm 0.7 \mathrm{mV}$ at $23^{\circ} \mathrm{C}$ to $-71.2 \pm 0.8 \mathrm{mV}$ at $32^{\circ} \mathrm{C}(p=0.0012, n=19)$.

\section{Afferent fiber membrane input resistance at} high temperature

The $\tau_{\text {decay }}$ of EPSPs decreased at high temperature in all of the fibers recorded (Fig. 3B3; Table 2), which may due to lower membrane input resistance $\left(\mathrm{R}_{\text {in }}\right)$ at high temperature. We thus estimated $\mathrm{R}_{\text {in }}$ of the afferent fibers using current clamp: $\mathrm{R}_{\text {in }}=\Delta \mathrm{V} / \Delta \mathrm{I}$, where $\Delta \mathrm{V}$ was the change in membrane potential induced by a $100 \mathrm{pA}$ current injection (Fig. $4 A$ ). The $\mathrm{R}_{\text {in }}$ of afferent fibers decreased from $557 \pm 128 \mathrm{M} \Omega$ at $22.0 \pm 0.1^{\circ} \mathrm{C}$ to $395 \pm 85 \mathrm{M} \Omega$ at $32.0 \pm 0.2^{\circ} \mathrm{C}(n=5, p=0.027)$. In this group of fibers, $\tau_{\text {decay }}$ of EPSPs was $6.5 \pm 2.7 \mathrm{~ms}$ and $3.3 \pm 1.7 \mathrm{~ms}$ at room and high temperature, respectively $(n=5, p=0.041)$. The $\tau_{\text {decay }}$ was positively correlated with afferent fiber $\mathrm{R}_{\text {in }}$ (linear regression slope $=$ $0.018 \pm 0.003, R^{2}=0.79, p=0.0006$; Fig. $4 B$, blue line).

An afferent fiber is composed of two compartments: a calyxtype ending that contacted the hair cell and a long, thin fiber cable. We thus fit the decay phase of membrane potential change to a step current with a double exponential function (gray dashed lines superimposed over $\mathrm{V}_{\mathrm{m}}$ trace; Fig. $4 A$, gray dashed lines superimposed over $\mathrm{V}_{\mathrm{m}}$ trace) as follows:

$$
I(t)=A_{1} \exp \left(-t / \tau_{1}\right)+A_{2} \exp \left(-t / \tau_{2}\right)+I_{s s}
$$

We can then calculate a weighted mean time constant $\tau_{\text {mean }}$ using the following: 


$$
\tau_{\text {mean }}=\frac{A_{1}}{A_{1}+A_{2}} \tau_{1}+\frac{A_{2}}{A_{1}+A_{2}} \tau_{2}
$$

The value of $\tau_{\text {mean }}$ was shorter at high temperature $(4.8 \pm 1.5 \mathrm{~ms})$ than that at room temperature $(7.8 \pm 1.5 \mathrm{~ms}, n=5, p=$ $0.0014)$. The $\tau_{1}$ at room and high temperature was $3.2 \pm 1.2 \mathrm{~ms}$ and $2.5 \pm 1.5 \mathrm{~ms}$, respectively, and the $\tau_{2}$ at room and high temperature was $10.3 \pm 1.3 \mathrm{~ms}$ and $6.0 \pm$ $1.7 \mathrm{~ms}$, respectively. The fact that a double exponential function with both fast $\left(\tau_{\mathrm{f}}\right)$ and slow $\left(\tau_{\mathrm{s}}\right)$ time constants is required to fit the voltage responses indicates that the afferent fiber is not isopotential (Golowasch et al., 2009), unlike the hair cell (see Fig. 6). Since the afferent axon has a cutoff end, due to the amphibian papilla isolation process, it can be modeled as a finite cable with an electrotonic length given by the following (Rall, 1969):

$$
L=\frac{\pi}{\sqrt{\frac{\tau_{s}}{\tau_{f}}-1}}
$$

We thus find that $L=2.1$ for $22^{\circ} \mathrm{C}$ and $L=2.6$ for $32^{\circ} \mathrm{C}$ for the afferent fibers. This is a relatively large value compared with hippocampal neurons where $L=0.9$ (Brown et al., 1981), suggesting a strong attenuation of the voltage from the postsynaptic calyx terminal to the tip of the cutoff and sealed afferent axon. Therefore, the cluster of $\mathrm{Na}^{+}$channels at the first axonal heminode must be fairly close to the calyx terminal to trigger a spike (Kim and Rutherford, 2016). By contrast, EPSP amplitude did not change significantly with temperature for this dataset $(6.5 \pm 0.7 \mathrm{mV}$ vs $9.3 \pm 2.2 \mathrm{mV}$ at $22.1 \pm$ $0.2^{\circ} \mathrm{C}$ and $32.0 \pm 0.1^{\circ} \mathrm{C}$, respectively; $\left.n=5, p=0.3\right)$. The linear regression of EPSP amplitude and $\mathrm{R}_{\mathrm{in}}$ also did not show a significant difference (slope $=-0.0016 \pm 0.005, R^{2}=0.013, p=$ $0.76)$. In conclusion, the $\mathrm{R}_{\text {in }}$ of afferent fibers exhibits significant heterogeneity from $100 \mathrm{M} \Omega$ to $1000 \mathrm{M} \Omega$, which could contribute to the in vivo variation in spontaneous spike rates and afferent fiber thresholds to sound stimulation (Stiebler and Narins, 1990; Shrestha et al., 2018).

Changes in $\mathrm{R}_{\text {in }}$ with temperature are also important because of membrane potential noise considerations (Fatt and Katz, 1952; Johnson, 1987). The mean square membrane voltage is given by the Nyquist theorem as follows:

$$
\overline{V_{m}^{2}}=4 k_{B} T \sqrt{\left(R_{i n} R_{a}\right)} \Delta f
$$

here $k_{B}$ is Boltzmann constant, T the temperature in degrees Kel$\operatorname{vin}(\mathrm{T}=273+$ temperature in Celsius $), \mathrm{R}_{\mathrm{in}}$ the membrane input resistance, $\mathrm{R}_{\mathrm{a}}$ the axial cable resistance and $\Delta f$ the noise frequency bandwidth. The frequency bandwidth is inversely proportional to the membrane time constant, which determines the cell cutoff frequency, and will thus increase at higher temperatures. The decrease in $\mathrm{R}_{\text {in }}$ with increasing temperature is thus important because it counteracts the increase in noise bandwidth with temperature. This helps to keep the membrane potential in a stable sub-threshold level.

\section{Resting membrane potential of hair cells}

The increase in EPSC frequency at high temperature suggests more spontaneous vesicle release from hair cells, which may be due to a depolarization of $\mathrm{V}_{\text {rest }}$ at high temperature. We thus measured hair cell $\mathrm{V}_{\text {rest }}$ under whole-cell current clamp with a holding current at 0 pA. Unexpectedly, whole-cell recordings revealed that $\mathrm{V}_{\text {rest }}$ hyperpolarized from $-65.0 \pm 1.8 \mathrm{mV}$ at $23.2 \pm 0.3^{\circ} \mathrm{C}$ to $-70.1 \pm 2.3 \mathrm{mV}$ at $31.2 \pm 0.3^{\circ} \mathrm{C}(p=0.006, n=$ 15; Fig. $5 A$, black circles). To prevent the dialysis of the hair cell constituents through the patch pipette, we also performed perforated-patch recordings using gramicidin $(40-50 \mu \mathrm{g} / \mathrm{ml})$. The perforated patch clamp showed that $\mathrm{V}_{\text {rest }}$ did not change at high temperatures $\left(\mathrm{V}_{\text {rest }}=-62.8 \pm 1.3 \mathrm{mV}\right.$ at $23.4 \pm 0.5^{\circ} \mathrm{C}$ and $\mathrm{V}_{\text {rest }}=-62.7 \pm 1.5 \mathrm{mV}$ at $31.6 \pm 0.2^{\circ} \mathrm{C}, p=0.88, n=9$; Fig. $5 \mathrm{~A}$, blue dots).

Hair cell potassium and calcium currents at high temperature Under voltage clamp and with a $\mathrm{K}^{+}$-based internal pipette solution, we determined the voltage-dependent currents that are ac- 

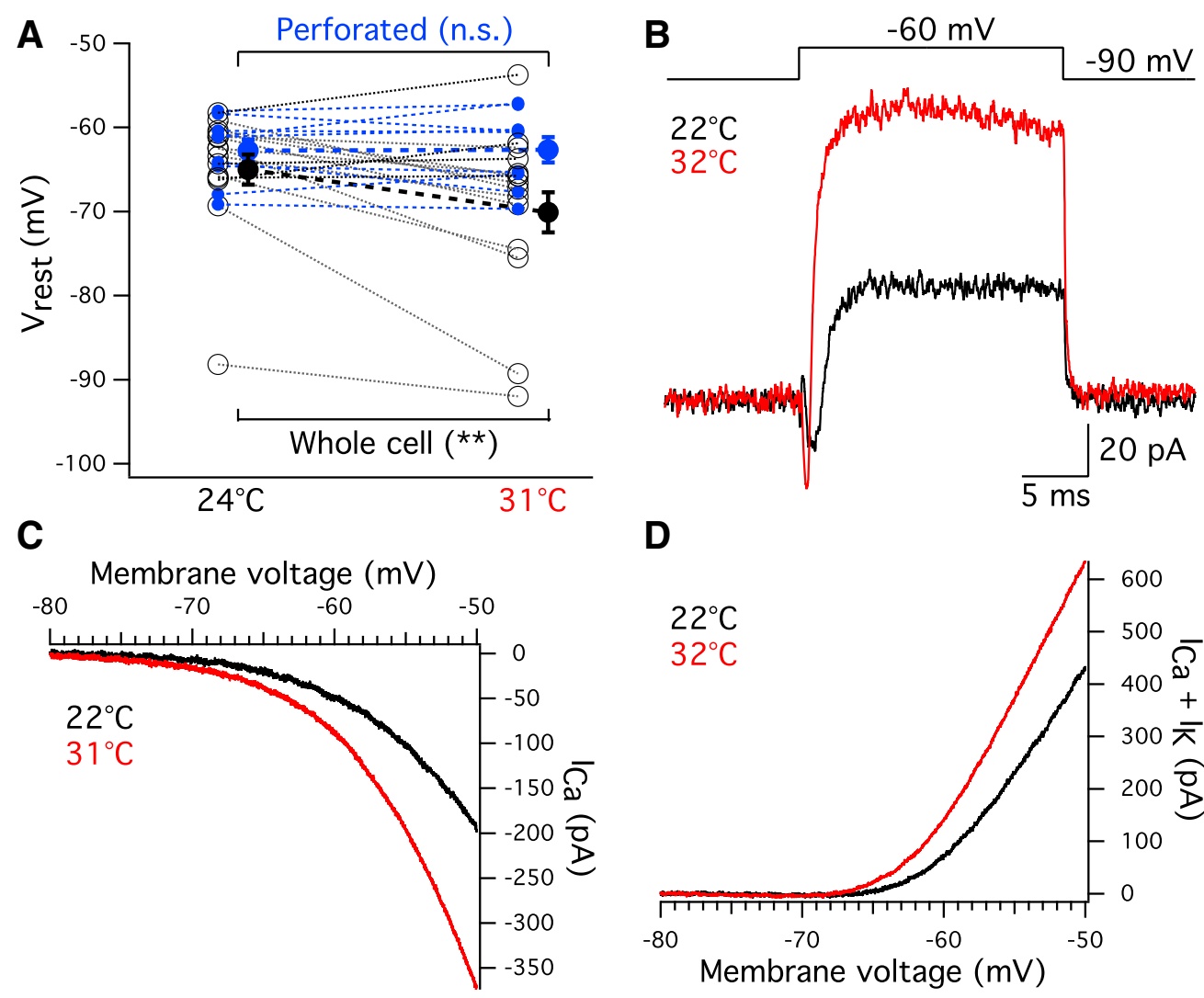

Figure 5. Hair cell resting membrane potential and ionic currents at high temperature. $A, \mathrm{AK}^{+}$-based internal pipette solution and current-clamp recordings with zero current injection were used to measure the $V_{\text {rest }}$ of hair cells. Whole-cell recordings showed that $V_{\text {rest }}$ hyperpolarized at high temperature (black circles, $\left.p=0.006, n=15\right)$. Gramicidin-mediated perforated patch recordings showed that $\mathrm{V}_{\text {rest }}$ remained the same at high temperature (blue dots, $p=0.88, n=9$ ). $\boldsymbol{B}$, Whole-cell voltage-clamp recordings of hair cells with $\mathrm{K}^{+}$-based internal solution showed current changes in response of a step depolarization from $-90 \mathrm{mV}$ to $-60 \mathrm{mV}$. The traces were averaged from five hair cells recorded at $22^{\circ} \mathrm{C}$ (black) and $32^{\circ} \mathrm{C}$ (red). Note the faster kinetics of the currents at $32^{\circ} \mathrm{C}$. C, To reveal $\mathrm{Ca}^{2+}$ current, hair cells were patched with a Cs ${ }^{+}$-TEA-based internal solution. Hair cells were depolarized with a ramp depolarization from $-90 \mathrm{mV}$ to $-50 \mathrm{mV}$ for $400 \mathrm{~ms}$ at $22^{\circ} \mathrm{C}$ (black) and $31^{\circ} \mathrm{C}\left(\right.$ red). The traces were averaged from five hair cells. D, Voltage-dependent $\mathrm{K}^{+}$and $\mathrm{Ca}^{2+}$ currents were triggered by the same ramp stimulus with $\mathrm{K}^{+}$-based internal solution. The traces were averaged from 14 hair cells recorded at $22^{\circ} \mathrm{C}$ (black) and $32^{\circ} \mathrm{C}\left(\right.$ red). Note how the larger outward $\mathrm{K}^{+}$currents dominate the hair cell $I-V$ curve. ${ }^{* *} p<0.01$.

tivated by a step-depolarization from -90 to $-60 \mathrm{mV}$. A rapidly activating inward current was followed by a rapid and large outward current (Fig. 5B). The inward current was a $\mathrm{Ca}^{2+}$ current that is activated more quickly at higher temperatures in frog hair cells (Hudspeth and Lewis, 1988). Using $\mathrm{Cs}^{+}$-TEA-based or $\mathrm{K}^{+}$based internal solutions, we recorded the $I-V$ curves of $\mathrm{Ca}^{2+}$ currents (Fig. 5C) and the overall $\mathrm{K}^{+}+\mathrm{Ca}^{2+}$ currents (Fig. 5D), respectively. Both types of currents increased in amplitude at high temperature. Importantly, the slope of voltage-dependent $\mathrm{Ca}^{2+}$ current was greater at high temperature, making $\mathrm{Ca}^{2+}$ influx more sensitive to small membrane potential changes. The increase in whole-cell outward $\mathrm{K}^{+}+\mathrm{Ca}^{2+}$ current at high temperature explains the decrease in $\mathrm{V}_{\text {rest }}$ with temperature (Fig. $5 \mathrm{~A}$, black circles). In perforated patch recordings, a lack of change in $\mathrm{V}_{\text {rest }}$ could be due to a simultaneous and more compensatory increase in inward $\mathrm{Ca}^{2+}$ current and outward $\mathrm{K}^{+}$current as temperature increases.

\section{Hair cell membrane input resistance decreases at high temperature}

At high temperature, an increase in $\mathrm{Ca}^{2+}$ and $\mathrm{K}^{+}$currents around $\mathrm{V}_{\text {rest }}$ should result in a decrease in membrane input resistance $\left(\mathrm{R}_{\text {in }}\right)$. To check this, we performed whole-cell voltage and current-clamp recordings from hair cells. In voltage clamp, hyperpolarizing hair cells from $-90 \mathrm{mV}$ to $-95 \mathrm{mV}$ or $-100 \mathrm{mV}$ for $10 \mathrm{~ms}$ elicited small inward currents (Fig. 6A1). $\mathrm{R}_{\text {in }}$ was cal- culated from Ohm's law $\left(\mathrm{R}_{\mathrm{in}}=\Delta \mathrm{V} / \Delta \mathrm{I}\right) . \mathrm{R}_{\mathrm{in}}$ of hair cells decreased at high temperature $\left(659.7 \pm 54.3 \mathrm{M} \Omega\right.$ at $23.2 \pm 0.2^{\circ} \mathrm{C}$ and $343.7 \pm 34.7 \mathrm{M} \Omega$ at $31.4 \pm 0.2^{\circ} \mathrm{C}, p=0.0006, n=7$; Fig. $\left.6 A 2\right)$. Under current clamp, injection of $-20 \mathrm{pA}$ or $-30 \mathrm{pA}$ hyperpolarized the cells (Fig. 6B1). Current clamp also showed a decrease in $\mathrm{R}_{\text {in }}$ at high temperature $\left(640.3 \pm 56.4 \mathrm{M} \Omega\right.$ at $23.2 \pm 0.2^{\circ} \mathrm{C}$ and $389.3 \pm 28.2 \mathrm{M} \Omega$ at $31.2 \pm 0.2^{\circ} \mathrm{C}, p=0.0023, n=7$; Fig. $6 B 2$ ). Changes in current or membrane potential were determined by calculating the differences between baseline and plateau (Fig. $6 A 1$, dashed lines, B1). There was no statistically significant difference in $\mathrm{R}_{\text {in }}$ measured with voltage clamp or current clamp at either room $(p=0.2598)$ or high $(p=0.7016)$ temperature $(n=7)$.

Some hair cells tend to be leakier toward the end of whole-cell recordings, and this may affect $\mathrm{R}_{\text {in }}$ (Ceballos et al., 2017). To control for this possibility, we first recorded $\mathrm{R}_{\text {in }}$ at room temperature and then heated the solution to high temperature. $\mathrm{R}_{\text {in }}$ decreased from $578.8 \pm 49.8 \mathrm{M} \Omega$ at $24.0 \pm 0.2^{\circ} \mathrm{C}$ to $315.8 \pm 33.3 \mathrm{M} \Omega$ at $31.5 \pm 0.2^{\circ} \mathrm{C}(p=0.0001, n=8)$. We then recorded from a distinct group of cells, first at high temperature and then at room temperature. $\mathrm{R}_{\text {in }}$ was also lower at high temperature $(600.2 \pm$ $38.2 \mathrm{M} \Omega$ at $24.1 \pm 0.1^{\circ} \mathrm{C}$ and $277.6 \pm 34.0 \mathrm{M} \Omega$ at $31.9 \pm 0.1^{\circ} \mathrm{C}$, $p=0.0146, n=3)$. Thus, the order of recording did not affect $\mathrm{R}_{\text {in }}$ measured at either room $(p=0.81)$ or high $(p=0.53)$ temperature. This suggests that the decrease in $\mathrm{R}_{\text {in }}$ at high temperature was not due to hair cells becoming leakier toward the end of the 
A1 Voltage clamp

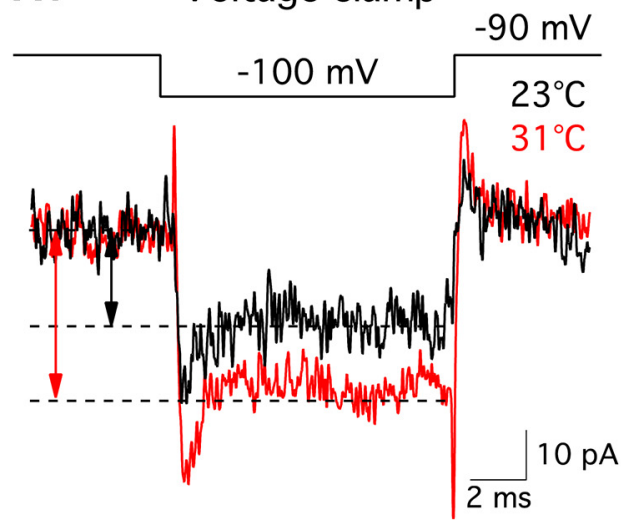

A2

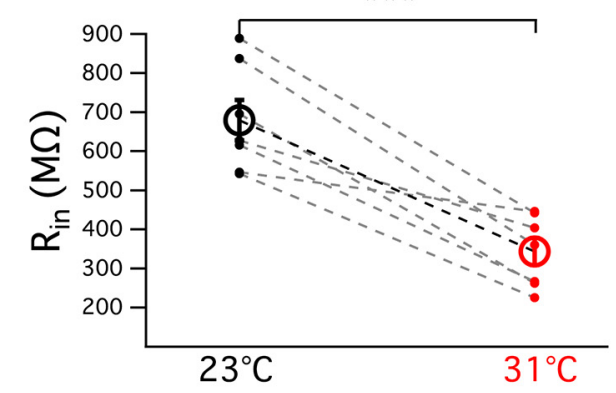

B3

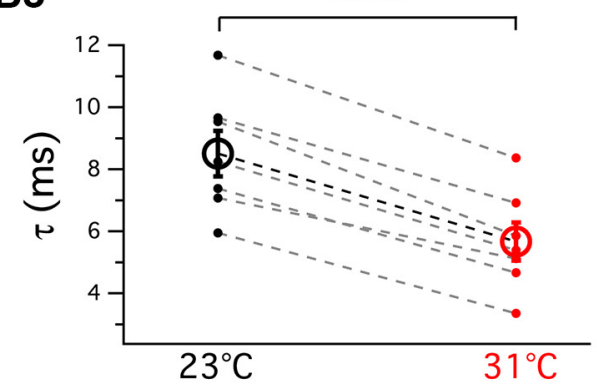

B1 Current clamp

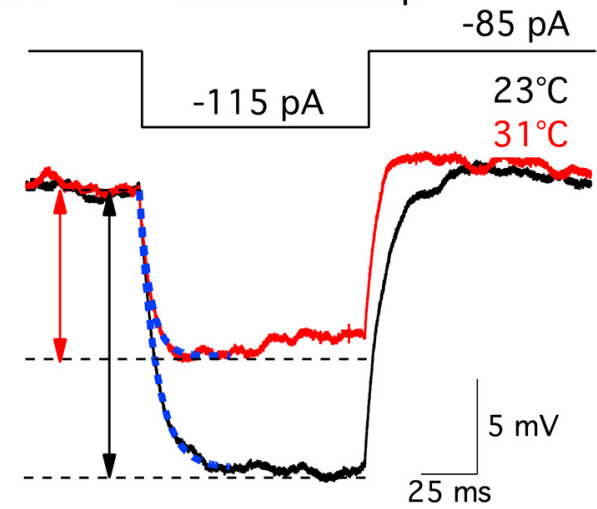

B2

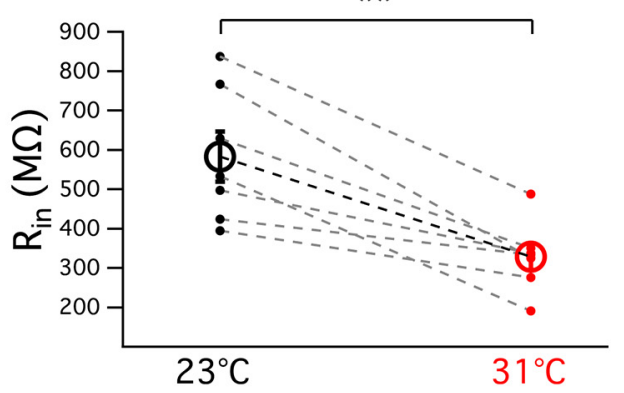

B4

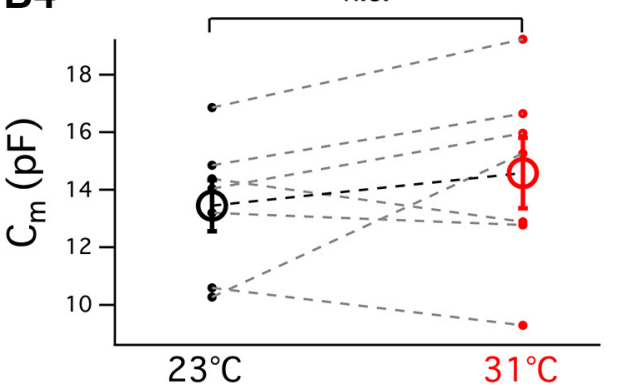

Figure 6. Temperature effects on hair cell passive membrane properties. $A 1$, Inward currents were triggered by a small hyperpolarization from -90 to $-100 \mathrm{mV}$ at $23^{\circ} \mathrm{C}(\mathrm{black})$ and $31^{\circ} \mathrm{C}(\mathrm{red})$. The size of the current was the difference between baseline and the plateau inward current (dashed lines). B1, Hyperpolarized membrane potential in response to a $-30 \mathrm{pA}$ current injection under current clamp was recorded at $23^{\circ} \mathrm{C}$ (black) and $31^{\circ} \mathrm{C}$ (red). The change in membrane potential was calculated by subtracting baseline from plateau (dashed lines). A2, Using voltage-clamp measurements and $\mathrm{R}_{\text {in }}=\Delta \mathrm{V} / \Delta \mathrm{I}$, the membrane input resistance $\left(\mathrm{R}_{\text {in }}\right)$ was lower at high temperature $(p=0.0006, n=7)$. $\boldsymbol{B}$, Current-clamp measurements also showed that $\mathrm{R}_{\text {in }}$ decreased at high temperature $(p=0.0031, n=7) \cdot B 3$, Membrane time constant $(\tau)$ was estimated by fitting a single exponential to a $40 \mathrm{~ms}$ time window of the voltage response following the initial current injection ( $\boldsymbol{B}$, superimposed blue dashed lines). $\tau$ was faster at high temperature $(p<0.0001, n=7) . B 4, C_{m}$ calculated using $C_{m}=\tau / R_{\text {in }}$ did not show significant change at high temperature $(p=0.2506, n=7) . A 2, B 2-B 4$, Dots represent individual values; open circles represent mean; bars represent SEM. ${ }^{* *} p<0.01,{ }^{* * *} p<0.001,{ }^{* * * *} p<0.0001$.

recordings, but due to an increase in cell membrane conductance at high temperature (Fig. 5B).

Using current-clamp data, we also calculated the membrane time constant $(\tau)$. We fitted a single exponential to a $40 \mathrm{~ms}$ time window of the voltage response following the initial current injection (Fig. 6B1, superimposed blue dashed line). The time constant was $8.50 \pm 0.73 \mathrm{~ms}$ at $23.2 \pm 0.2^{\circ} \mathrm{C}$ and $5.67 \pm 0.61 \mathrm{~ms}$ at $31.2 \pm 0.2^{\circ} \mathrm{C}(p<0.0001, n=7$; Fig. 6 B3 $)$. We next determined the membrane capacitance $\left(C_{m}\right)$ using the equation $C_{m}=\tau / R_{i n}$. The average value of $\mathrm{C}_{\mathrm{m}}$ remained the same regardless of temperature changes $\left(13.5 \pm 0.9 \mathrm{pF}\right.$ at $23.2 \pm 0.2^{\circ} \mathrm{C}$ and $14.6 \pm 1.2 \mathrm{pF}$ at $31.2 \pm 0.2^{\circ} \mathrm{C}, p=0.2506, n=7$; Fig. $\left.6 B 4\right)$. This value of $\mathrm{C}_{\mathrm{m}}$ is similar to previous whole-cell recordings in voltage clamp of $\mathrm{C}_{\mathrm{m}}$ in bullfrog hair cells ( $\mathrm{Li}$ et al., 2009). This agreement between voltage and current-clamp values for $R_{i n}$ and $C_{m}$ is expected only for isopotential cells (Golowasch et al., 2009).
Electrical resonant frequency increases at high temperature Unlike mechanical tuning in the mammalian cochlea, amphibian papilla hair cells in frogs are electrically tuned (Smotherman and Narins, 2000). Electrical resonance of amphibian papilla hair cells matches the characteristic (best) frequencies of the afferent fibers (Smotherman and Narins, 1999). The electrical resonance is a result of the interplay of voltage-gated ion channels and membrane capacitance (Crawford and Fettiplace, 1981; Art and Fettiplace, 1987; Hudspeth and Lewis, 1988). Since the conductance of voltage-gated calcium and potassium channels are temperaturedependent as shown in Figure 5, we expect electrical resonance to be temperature-sensitive. To elicit electrical ringing around resting membrane potentials, hair cells were injected a current step from zero current under whole-cell (Fig. $7 A$ ) or perforated patch clamp (Fig. 7B). Resonant frequency was estimated by fitting the first $20 \mathrm{~ms}$ of the damped oscillation in membrane voltage with a 

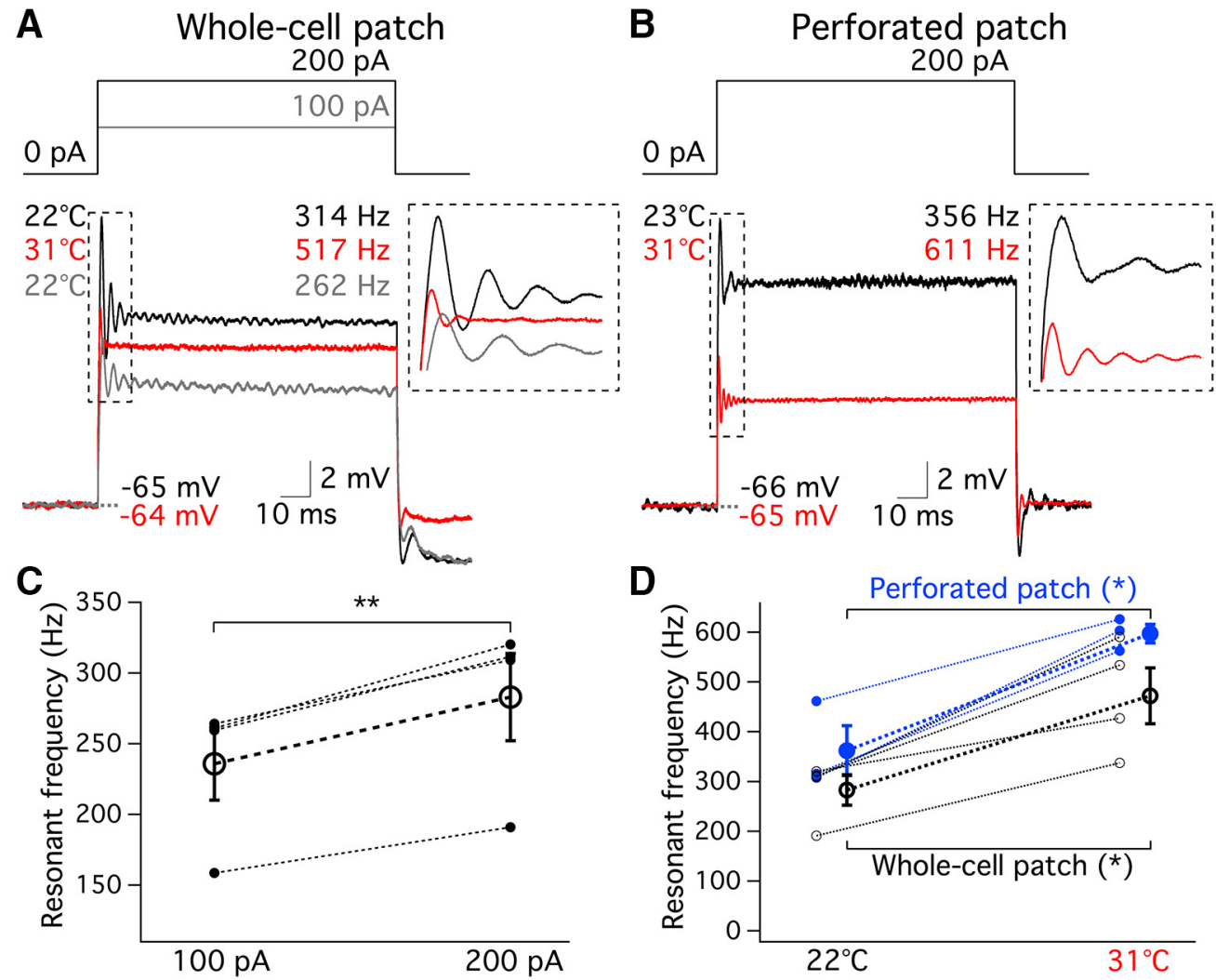

Figure 7. Hair cell resonant frequency increases at high temperature. $A$, Electrical resonance was elicited by stimulating hair cells with a current step in whole-cell patch. Black and red traces were evoked by a $200 \mathrm{pA}$ current step at room and high temperature, respectively. Gray trace was evoked by a $100 \mathrm{pA}$ current step at room temperature. Each of these three traces is the average response from three hair cells. Resonant frequencies were calculated by fitting the first $20 \mathrm{~ms}$ membrane voltage changes with a sine wave function (dashed line box inset). The resonant frequencies of black, red, and gray traces were 314,517 , and $262 \mathrm{~Hz}$, respectively. $\boldsymbol{B}$, Electrical resonance of hair cells was elicited by a $200 \mathrm{pA}$ current step in gramicidine-mediated perforated patch. Black and red traces were averaged of 3 cells recorded at room and high temperature, respectively. The resonant frequencies of black and red traces were $356 \mathrm{and} 611 \mathrm{~Hz}$, respectively. $\boldsymbol{C}$, Resonant frequencies of hair cells evoked by $100 \mathrm{pA}$ current steps were lower than those evoked by $200 \mathrm{pA}$ current steps $(n=4, p=0.004)$. $\boldsymbol{D}$, Results of both whole-cell (black, $n=4, p=0.017)$ and perforated (blue, $n=3, p=$ 0.025 ) patch recordings showed that resonant frequency of hair cells increased significantly at high temperature. There was no statistical difference between resonant frequencies measured by whole-cell patch or perforated patch at either room ( $p=0.80$, unpaired $t$ test $)$ or high $\left(p=0.56\right.$, unpaired $t$ test) temperature. ${ }^{*} p<0.05,{ }^{* *} p<0.01$.

sine wave function (Li et al., 2014). In a previous study (Smotherman and Narins, 1999), it was shown that resonant frequency increases as larger depolarizing current steps are applied to the cell. Consistently, depolarizing hair cells with $100 \mathrm{pA}$ current steps elicited a resonant frequency of $236 \pm 26 \mathrm{~Hz}$, while $200 \mathrm{pA}$ current steps elicited a higher resonant frequency of $283 \pm 31 \mathrm{~Hz}$ at room temperature ( $p=0.0038, n=4$; Fig. $7 A, C)$. To compare the resonant frequency measured with whole-cell recordings to perforated patch recordings, we chose the larger $200 \mathrm{pA}$ current steps. The resonant frequency increased from $283 \pm 31 \mathrm{~Hz}$ at $21.8 \pm 0.4^{\circ} \mathrm{C}$ to $472 \pm 56 \mathrm{~Hz}$ at $31.4 \pm 0.6^{\circ} \mathrm{C}(p=0.017, n=4$; Fig. $7 D$, black circle). Similarly, perforated patch recordings revealed that resonant frequency increased from $362 \pm 50 \mathrm{~Hz}$ at $24.8 \pm 2.1^{\circ} \mathrm{C}$ to $597 \pm 19 \mathrm{~Hz}$ at $31.5 \pm 0.3^{\circ} \mathrm{C}(p=0.025, n=3$; Fig. $7 D$, blue dots). There was no statistical difference in resonant frequency measured by whole-cell recording and perforated patch at either room ( $p=0.22$, unpaired $t$ test $)$ or high $(p=0.13$, unpaired $t$ test) temperatures.

Hair cell resonant frequency also increases when resting membrane potential is depolarized (Hudspeth and Lewis, 1988; Smotherman and Narins, 1999). However, the resting membrane potential did not change for the whole-cell recordings of Figure $7 A(-65.2 \pm 0.5 \mathrm{mV}$ at room temperature vs $-63.8 \pm 0.8 \mathrm{mV}$ at high temperature, $p=0.23, n=4)$. Similarly, resting membrane potential did not change with temperature for the perforated patch data $(-66.0 \pm 2.7 \mathrm{mV}$ at room temperature vs $-65.2 \pm 2.6$
$\mathrm{mV}$ at high temperature, $p=0.51, n=3)$. Therefore, the increases of resonant frequency at high temperature are not due to changes in resting membrane potential. Instead, they are caused by faster activation and larger conductance of $\mathrm{Ca}^{2+}$ and $\mathrm{K}^{+}$ channels upon depolarization at high temperature (Hudspeth and Lewis, 1988; Smotherman and Narins, 1999). The resonant frequency measured at room temperature matches the results of in vitro whole-cell recordings of hair cells from amphibian papilla using a ZAP protocol (Frolov and Li, 2017). The $\mathrm{Q}_{10}$ of resonant frequency of amphibian papilla hair cells $(1.7 \pm 0.1, n=4$ for whole cell; $1.9 \pm 0.08, n=3$ for perforated patch) are similar to that recorded from frog saccular hair cells (Smotherman and Narins, 1998). This temperature-dependent shift in hair cell resonant frequency may be responsible for the temperature-induced shifts of best frequency observed at in vivo amphibian papilla auditory nerve fiber recordings (Stiebler and Narins, 1990).

\section{Release efficiency increases at high temperature}

A lower $R_{\text {in }}$ at high temperature results in smaller membrane potential changes, which will decrease hair cell sensitivity to lowlevel sounds. To explore whether hair cells compensate for this putative loss in sensitivity, we studied the temperature dependence of vesicle exocytosis from hair cells using time-resolved membrane capacitance measurements (Lindau and Neher, 1988; Gillis, 2000). Changes in $C_{m}\left(\Delta C_{m}\right)$ were evoked by depolarizing voltage steps. We first used $20 \mathrm{~ms}$ depolarizing steps from a hold- 
ing potential of -90 to $-30 \mathrm{mV}$ to evoke fast release that depletes the RRP consisting of vesicles docked near the clustered $\mathrm{Ca}^{2+}$ channels (Graydon et al., 2011) (Fig. 8A1). The depolarization triggered a larger $\mathrm{Ca}^{2+}$ current (Fig. 8A1) under high temperature than under room temperature $(p<0.0001, n=7): \mathrm{Ca}^{2+}$ charge transfer $\left(\mathrm{Q}_{\mathrm{Ca}}\right)$ was $11.9 \pm 1.3 \mathrm{pC}$ at $23.3 \pm$ $0.2^{\circ} \mathrm{C}$ and $15.9 \pm 1.7 \mathrm{pC}$ at $32.0 \pm 0.3^{\circ} \mathrm{C}$. The $\mathrm{Q}_{10}$ of $20 \mathrm{~ms}$ pulse-evoked $\mathrm{Q}_{\mathrm{Ca}}$ was $1.5 \pm 0.05(n=7)$. Average resting membrane capacitance measured at high temperature $(16.9 \pm 0.7 \mathrm{pF})$ was similar to that measured at room temperature $(15.7 \pm 0.6 \mathrm{pF}, p=0.0841, n=7)$. The $\Delta \mathrm{C}_{\mathrm{m}}$ increased from $27.2 \pm 4.7 \mathrm{fF}$ at room temperature to $51.6 \pm 6.0 \mathrm{fF}$ at high temperature $(p=0.0006, n=7)$. The $\mathrm{Q}_{10}$ of $20 \mathrm{~ms}$ pulse-evoked $\Delta \mathrm{C}_{\mathrm{m}}$ was $2.4 \pm 0.4$ $(n=7)$.

Here, $Q_{10}$ is the ratio of the reaction rates for $\mathrm{T}_{\mathrm{L}}=296^{\circ} \mathrm{K}\left(23^{\circ} \mathrm{C}\right)$ and for $\mathrm{T}_{\mathrm{H}}=$ $\mathrm{T}_{\mathrm{L}}+10^{\circ} \mathrm{K}=306^{\circ} \mathrm{K}$ as follows:

$$
Q_{10}=\frac{\operatorname{Rate}\left(T_{H}\right)}{\operatorname{Rate}\left(T_{L}\right)}=\frac{e^{-\frac{E_{a}}{k_{B} T_{H}}}}{e^{-\frac{E_{a}}{k_{B} T_{L}}}}
$$

where $k_{B} \approx 8.3 \mathrm{~J} / \mathrm{mol}^{\circ} \mathrm{K}$ (Boltzmann constant) and $E_{a}$ is the reaction activation energy barrier. From this equation, we obtain $E_{a}=\left(\ln Q_{10}\right) \cdot 75.2 \mathrm{~kJ} / \mathrm{mol}$. The $E_{a}$ for evoked exocytosis was thus $65.8 \pm$ $10.0 \mathrm{~kJ} / \mathrm{mol} \approx 26.8 \mathrm{k}_{\mathrm{B}} \mathrm{T}(n=7)$, which was calculated from the $\mathrm{Q}_{10}$ of $20 \mathrm{~ms}$ depolarizing pulses. This is within the $\mathrm{E}_{\mathrm{a}}$ estimated for vesicle exocytosis mediated by SNAREpin and synaptotagmin molecules (20-140 k $\mathrm{k}_{\mathrm{B}} \mathrm{T}$ ) (Zhang and Jackson, 2008; Schotten et al., 2015; Mostafavi et al., 2017), although exocytosis in hair cells is mediated by otoferlin (Michalski et al., 2017).

Depolarizations from -90 to $-30 \mathrm{mV}$ for $200 \mathrm{~ms}$ (Fig. 8B1) not only depletes the RRP but also evokes sustained release of vesicles replenishing to the RRP (Graydon et al., 2011). $\mathrm{Q}_{\mathrm{Ca}}$ evoked by the $200 \mathrm{~ms}$ depolarizing pulse was $99.7 \pm 8.0 \mathrm{pC}$ at $23.1 \pm 0.2^{\circ} \mathrm{C}$ and $126.3 \pm 9.7 \mathrm{pC}$ at $31.3 \pm 0.2^{\circ} \mathrm{C}(p<0.0001, n=$ 15). $\Delta \mathrm{C}_{\mathrm{m}}$ evoked by $200 \mathrm{~ms}$ depolarizing steps increased from $109.8 \pm 9.1 \mathrm{fF}$ at room temperature to $192.1 \pm 21.2 \mathrm{fF}$ at high temperature $(p<0.0001, n=15)$. The $\mathrm{Q}_{10}$ of $\mathrm{Q}_{\mathrm{Ca}}$ and $\Delta \mathrm{C}_{\mathrm{m}}$ evoked by a $200 \mathrm{~ms}$ pulse was $1.3 \pm 0.04$ and $2.0 \pm 0.1(n=15)$, respectively. The $\mathrm{Q}_{10}$ of exocytosis from bullfrog hair cells is close to that found in mouse inner hair cells using capacitance measurements $\left(Q_{10}=2.1\right)$ (Nouvian, 2007) and in rat hippocampal neurons using FM1-43 destaining methods $\left(\mathrm{Q}_{10}=2.5\right)$ (Yang et al., 2005).

Plotting $\Delta \mathrm{C}_{\mathrm{m}}$ versus the corresponding $\mathrm{Q}_{\mathrm{Ca}^{2+}}$, we obtained the efficiency of exocytosis as the ratio of $\Delta \mathrm{C}_{\mathrm{m}} / \mathrm{Q}_{\mathrm{Ca}^{2+}}$, which for $20 \mathrm{~ms}$ pulses increased from $3.0 \pm 0.8 \mathrm{fF} \cdot \mathrm{pC}^{-1}$ at room temperature to $4.7 \pm 1.0 \mathrm{fF} \cdot \mathrm{pC}^{-1}$ at high temperature $\left(p=0.0043, n=7 ; \mathrm{Q}_{10}\right.$ $=1.9 \pm 0.3$; Fig. 8A2). The ratio of $\Delta \mathrm{C}_{\mathrm{m}} / \mathrm{Q}_{\mathrm{Ca}^{2+}}$ for responses to $200 \mathrm{~ms}$ pulses increased from $1.2 \pm 0.1 \mathrm{fF} \cdot \mathrm{pC}^{-1}$ at room temperature to $1.6 \pm 0.2 \mathrm{fF} \cdot \mathrm{pC}^{-1}$ at high temperature $(p=0.0013$, $n=15$; Fig. 8B2). Recordings from mouse IHC also find that higher temperatures enhance $\mathrm{Ca}^{2+}$ influx and increase $\Delta \mathrm{C}_{\mathrm{m}} / \mathrm{Q}_{\mathrm{Ca}^{2+}}$ elicited by $20 \mathrm{~ms}$ depolarizing pulses, but not for sustained exocytosis (Nouvian, 2007). By contrast, our results with bullfrog hair cells indicate that the efficiency of both fast and sustained exocytosis increased under high temperature.

To further demonstrate that the increase in exocytosis is facilitated beyond a mere increase of $\mathrm{Ca}^{2+}$ influx under high temperature, we reduced $\mathrm{Ca}^{2+}$ influx using smaller depolarizing potentials at high temperature and measured $\Delta \mathrm{C}_{\mathrm{m}}$ jumps. We also used the $\mathrm{pH}$-insensitive $\mathrm{Ca}^{2+}$ buffer BAPTA (Tsien, 1980) and a different $\mathrm{pH}$ buffer MOPS, which has similar temperature dependence with HEPES (Ellis and Morrison, 1982). A depolarization from $-90 \mathrm{mV}$ to a potential that varied from -46 to -56 $\mathrm{mV}$ (average: $-50.6 \pm 1.8 \mathrm{mV}, n=9$ ) for $20 \mathrm{~ms}$ at $32^{\circ} \mathrm{C}$ elicited similar or less $\mathrm{Ca}^{2+}$ influx $(6.4 \pm 0.8 \mathrm{pC})$ to that triggered by 20 $\mathrm{ms}$ depolarization to $-30 \mathrm{mV}$ at $23^{\circ} \mathrm{C}(8.7 \pm 1.2 \mathrm{pC}, p=0.0059$, $n=9$; Fig. 9A). However, even when $\mathrm{Ca}^{2+}$ influx was reduced, hair cells were still able to release more vesicles upon depolarization at high temperature (Fig. $9 A$ ). $\Delta \mathrm{C}_{\mathrm{m}}$ increased from $10.3 \pm$ $1.3 \mathrm{fF}$ at room temperature to $19.2 \pm 2.6 \mathrm{fF}$ at high temperature $(p=0.0028, n=9$; Fig. 9B). Consistent with previous results using internal EGTA and HEPES, exocytosis efficiency increased from $1.3 \pm 0.2$ at room temperature to $3.7 \pm 0.8$ at 
A
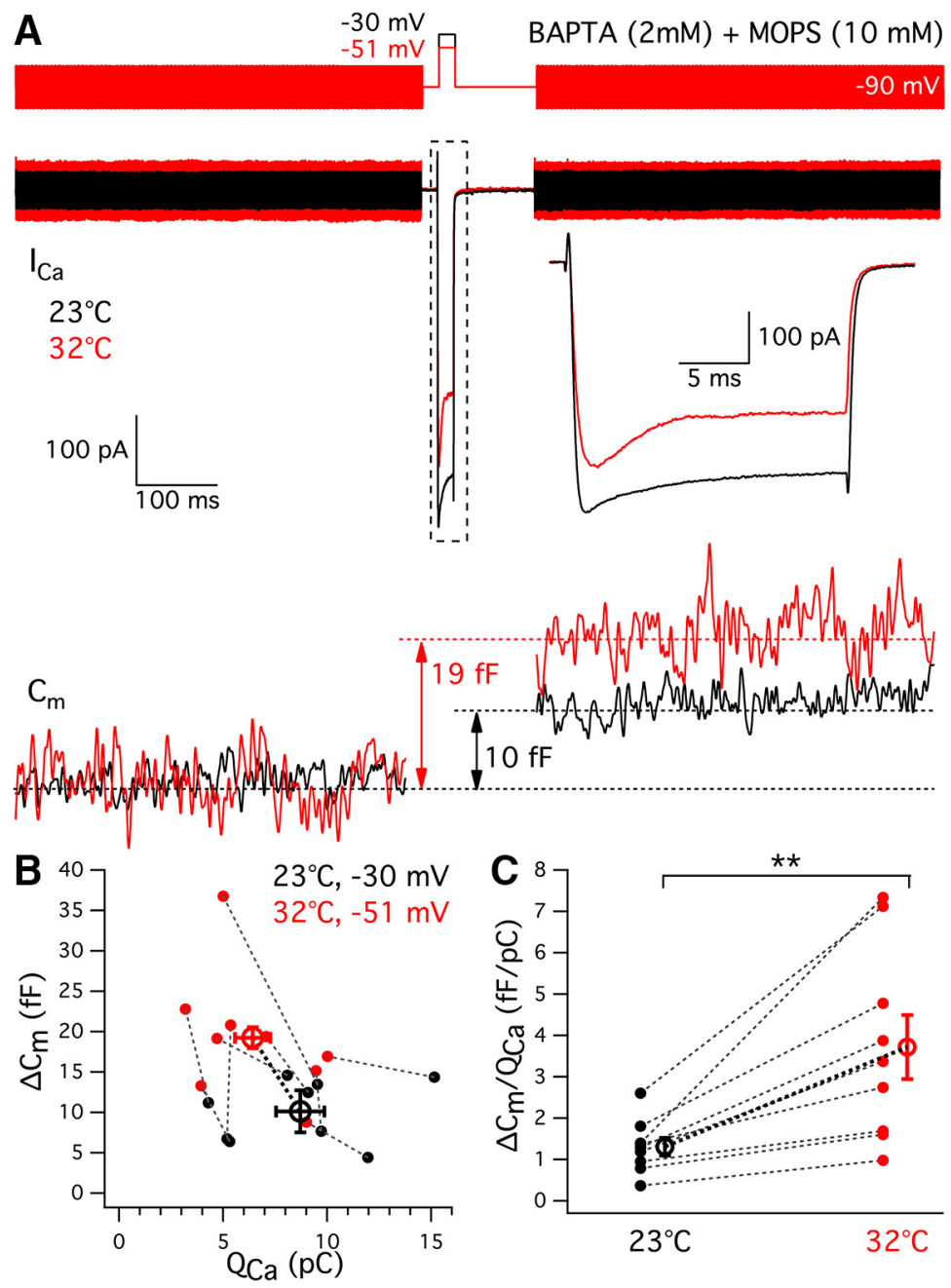

Figure 9. Exocytosis increases at high temperature, even when $\mathrm{Ca}^{2+}$ influx is reduced. $\boldsymbol{A}$, The depolarization potential at high temperature was adjusted between $-45 \mathrm{and}-55 \mathrm{mV}$ to elicit the same or less amount of $\mathrm{Ca}^{2+}$ influx to that at room temperature. To exclude temperature effects on $\mathrm{pH}$ or $\mathrm{Ca}^{2+}$ buffering, hair cells were patched with internal solution containing $\mathrm{pH}$ insensitive $\mathrm{Ca}^{2+}$ buffer BAPTA $(2 \mathrm{mM})$ and a different pH buffer MOPS $(10 \mathrm{~mm})$. Averages of $\mathrm{Ca}^{2+}$ currents $\left(\mathrm{I}_{\mathrm{Ca}}\right)$ from nine hair cells triggered by depolarization to $-30 \mathrm{mV}$ at $23^{\circ} \mathrm{C}$ (black) and to $-51 \pm 2 \mathrm{mV}$ at $32^{\circ} \mathrm{C}\left(\right.$ red). The $\mathrm{I}_{\mathrm{Ca}}$ was expanded in time scale from the one in a dashed line box. The membrane capacitance change $\left(\Delta C_{m}\right)$ was $10 \mathrm{fF}$ at $23^{\circ} \mathrm{C}$ (black) and $19 \mathrm{fF}$ at $32^{\circ} \mathrm{C}(\mathrm{red}) . B, \Delta C_{\mathrm{m}}$ versus $Q_{C_{a}}$ from individual hair cells depolarized to $-30 \mathrm{mV}$ at $23^{\circ} \mathrm{C}$ (black) and to $-51 \mathrm{mV}$ at $32^{\circ} \mathrm{C}$ (red). Data points connected by a dashed line were recorded from the same hair cell. $C$, Exocytosis efficiency $\left(\Delta \mathrm{C}_{\mathrm{m}} / \mathrm{Q}_{\mathrm{Ca}^{2+}}\right)$ increased from $23^{\circ} \mathrm{C}$ (black) to $32^{\circ} \mathrm{C}$ (red; $p=0.0042, n=9$ ). ${ }^{* *} p<0.01$.

high temperature $(p=0.0042, n=9$; Fig. $9 C)$. The results indicate that high temperature facilitates synaptic vesicle exocytosis, even when $\mathrm{Ca}^{2+}$ influx is reduced. Moreover, the effect is not due to temperature-dependent changes in cellular $\mathrm{pH}$-dependent $\mathrm{Ca}^{2+}$ buffering.

\section{RRP size is larger at high temperature}

To compare the maximum size of hair cell RRP under room and high temperature, we used a dual-pulse protocol (Gillis et al., 1996). Two pulses of $100 \mathrm{~ms}$ duration are given with a $25 \mathrm{~ms}$ interval (Fig. 10A). The short $25 \mathrm{~ms}$ interval results in depression in the second release. $\mathrm{Ca}^{2+}$ current can also decline during the dual pulse due to inactivation. To avoid differences in $\mathrm{Q}_{\mathrm{Ca}}$ during the first and second depolarization, the potentials of the first pulses are adjusted (Fig. 10A). The average of the first depolarizing potentials was $-41.1 \pm 0.7 \mathrm{mV}(n=11)$. The intervals between pulse pairs was $60-90 \mathrm{~s}$ to allow for full recovery. Under $23^{\circ} \mathrm{C}$, the $\mathrm{Ca}^{2+}$ influx during the first and second depolarizing pulses was $31.8 \pm 6.8$ and $31.7 \pm 6.8 \mathrm{pC}$, respectively $(n=4, p=0.93$; Fig. $10 A, C)$. Under $31^{\circ} \mathrm{C}$, the $\mathrm{Ca}^{2+}$ influx during the first and second depolarizing pulses was $62.8 \pm 3.8$ and $63.3 \pm 3.1 \mathrm{pC}$, respectively $(n=7, p=0.69$; Fig. $10 A, C)$. Consistently, both the first $(p=0.0019)$ and the second ( $p=0.0009$; Fig. $10 C)$ pulses triggered more $\mathrm{Ca}^{2+}$ influx under high temperature. $\Delta \mathrm{C}_{1}$ and $\Delta \mathrm{C}_{2}$ were capacitance jumps triggered by the first and second depolarization. The maximum size of the RRP $\left(\mathrm{B}_{\max }\right)$ was calculated according to the following:

$$
B_{\text {max }}=\frac{\Delta C_{1}+\Delta C_{2}}{1-\left(\Delta C_{2} / \Delta C_{1}\right)^{2}}
$$

This equation from Gillis et al. (1996) is derived based on the assumption that the same fraction of the pool is released with each pulse. If there is a larger fraction of release during the second pulse (e.g., due to residual $\mathrm{Ca}^{2+}$ from the first pulse) or significant numbers of vesicles have been refilled during the second pulse, then $B_{\max }$ will overestimate the actual initial pool size. Therefore, the actual pool size lies between $\Delta \mathrm{C}_{1}$ and $\mathrm{B}_{\max }$. In the example of Figure $10 \mathrm{~A}$, the $\mathrm{B}_{\text {max }}$ increased from $143 \mathrm{pF}$ at $23^{\circ} \mathrm{C}$ to $175 \mathrm{pF}$ at $31^{\circ} \mathrm{C}$. On average, the $\mathrm{B}_{\max }$ increased from $83 \pm 20 \mathrm{fF}(n=4)$ at room temperature to $246 \pm 47 \mathrm{fF}$ at high temperature $(n=7, p=0.0351$, unpaired $t$ test; Fig. 10B). These results showing an increase in RRP size with increasing temperature are similar to those reported for chromaffin cell exocytosis (Dinkelacker et al., 2000). In addition, the paired-pulse ratio $\Delta \mathrm{C}_{2} / \Delta \mathrm{C}_{1}$ did not change significantly upon temperature shift: $0.46 \pm 0.19$ at room temperature $(n=4)$ versus $0.69 \pm 0.05$ at high temperature ( $n=7, p=0.18$; unpaired $t$ test). This suggests that evoked release probability does not change with temperature shifts.

\section{Ultrafast $\mathrm{Ca}^{2+}$ currents and short synaptic delays at high temperature}

In vivo recordings of the auditory nerve fibers of two different species of frogs, Hyla regilla and Eleutherodactylus coqui, showed that the latencies of the first spike after the onset of a sound stimulus decreased when increasing temperature from $12^{\circ} \mathrm{C}$ to $25^{\circ} \mathrm{C}$ (Stiebler and Narins, 1990). To determine the temperature dependence of the synaptic delay at the hair cell afferent synapse, we performed paired recordings. We depolarized hair cells with two $20 \mathrm{~ms}$ depolarizing steps from -90 to $-30 \mathrm{mV}$ with $50 \mathrm{~ms}$ intervals (Fig. 11A) and recorded evoked EPSCs mediated by activation of AMPA receptors in the afferent fiber. After depolarization, $\mathrm{Ca}^{2+}$ ions entered into hair cells and triggered glutamate release (Fig. 11A). Due to EPSC rundown in some paired recordings, we only included the first trial from each pair in our analysis. 
Therefore, the data obtained at room and high temperatures were from two different groups of pairs. The average of EPSCs recorded at $22^{\circ} \mathrm{C}(n=3)$ and $31^{\circ} \mathrm{C}(n=6)$ is shown in black and red, respectively (Fig. 11A). Synaptic delay was measured from the onset of the pulse until the EPSC reached $10 \%$ of its maximum (Fig. 11C). The synaptic delay of the first EPSC (Fig. $11 C)$ decreased from $2.03 \pm 0.16 \mathrm{~ms}$ at room temperature $(n=3)$ to $1.28 \pm 0.15$ $\mathrm{ms}$ at high temperature $(n=6, p=$ 0.0183 , unpaired $t$ test; Fig. $11 E$ ). The synaptic delay of the second EPSC (Fig. 11C) shortened from $1.26 \pm 0.10 \mathrm{~ms}$ at room temperature $(n=3)$ to $0.72 \pm 0.05 \mathrm{~ms}$ at high temperature $(n=6, p=0.001$, unpaired $t$ test; Fig. $11 E$ ). The first synaptic delay was longer than the second one under both room $(n=3, p=0.008)$ and high $(n=6, p=0.0206)$ temperature (Fig. $11 D, E)$. The synaptic delay we measured from adult frog hair cell synapses is much shorter than that of the immature rat inner hair cell synapse (Goutman and Glowatzki, 2011).

Shorter synaptic delay is partially due to faster activation of $\mathrm{Ca}^{2+}$ current at high temperature. To determine the effect of temperature on the activation of $\mathrm{I}_{\mathrm{Ca}}$, we used $\mathrm{P} / 4$ leak subtraction to eliminate the capacitive transient. The $\mathrm{Ca}^{2+}$ current was evoked by a $20 \mathrm{~ms}$ depolarizing step from -90 to $-30 \mathrm{mV}$ (Fig. $11 B$ ). By fitting the activation phase of the $\mathrm{Ca}^{2+}$ current with a single exponential function (Fig. 11B, dashed lines), we calculated the time constant of activation: $377 \pm 30 \mu$ s at $23.9 \pm 0.1^{\circ} \mathrm{C}$ and $219 \pm 19 \mu$ s at $31.5 \pm$ $0.3^{\circ} \mathrm{C}(p<0.0001, n=8)$. The corresponding $\mathrm{Q}_{10}$ was $2.2 \pm 0.2(n=8)$, which is similar to the $\mathrm{Q}_{10}$ of L-type $\mathrm{Ca}^{2+}$ channels activation in chick sensory neurons (Acerbo and Nobile, 1994), but higher than the $\mathrm{Q}_{10}$ of gerbil inner hair cells (Johnson and Marcotti, 2008). The results indicate that high temperature speeds up the activation of $\mathrm{Ca}^{2+}$ channels and thus contributes to shortening the synaptic delay.

Paired-pulse ratio calculated from the charge transfer of EPSCs $\left(\mathrm{EPSC}_{2} / \mathrm{EPSC}_{1}\right)$ was $1.00 \pm 0.05$ at room temperature $(n=3)$ and $0.92 \pm 0.02$ at high temperature $(n=6, p=0.25$, unpaired $t$ test). Together with the paired-pulse ratio $\Delta C_{2} / \Delta C_{1}$, this suggests that high temperature does not affect overall release probability. However, high temperature improves temporal precision by shortening the synaptic delay; and under both temperatures, hair cell synapses exhibit pronounced short-term facilitation (Goutman and Glowatzki, 2011; see also Cho et al., 2011). Interestingly, these results differ greatly from those found in a conventional active zone synapse, the calyx of Held synapse, where synaptic delay of the second pulse was longer and EPSCs exhibit pronounced short-term depression (Wu and Borst, 1999).
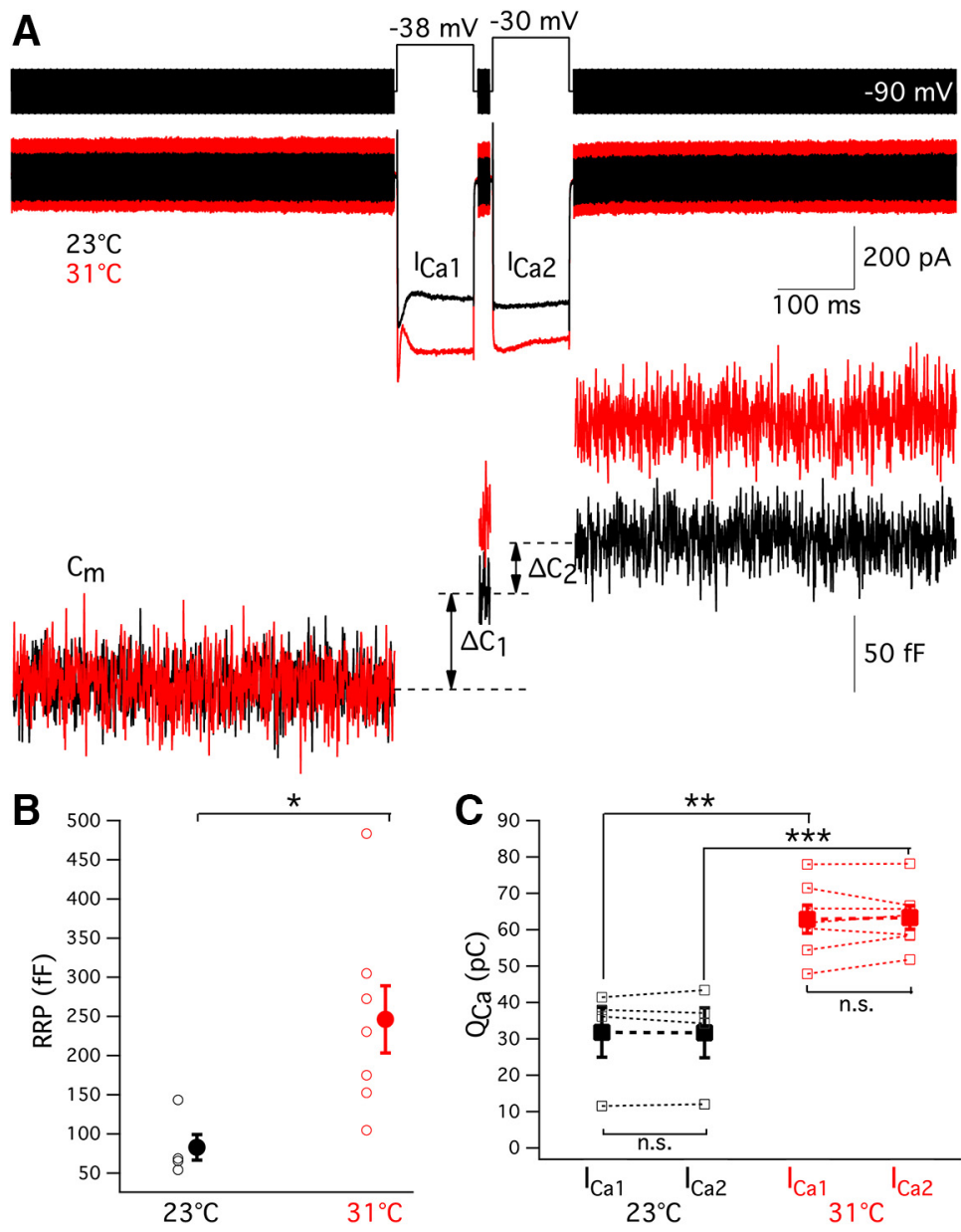

Figure 10. The RRP of vesicles is larger at high temperature. $\boldsymbol{A}$, The paired pulse protocol used to calculate the maximum size of exple, the first depolarizing potential was $-38 \mathrm{mV}$. The intervals between pulse pairs was $60-90 \mathrm{~s}$ to allow for full recovery. 作 by the first and second depolarization, respectively. $\boldsymbol{B}$, The maximum size of the RRP was calculated according to $B_{\max }=\frac{\Delta C_{1}+\Delta C_{2}}{1-\left(\Delta C_{2} / \Delta C_{1}\right)^{2}}$. The value of $\mathrm{B}_{\max }$ increased significantly from $\sim 83 \mathrm{fF}(n=4)$ at $23^{\circ} \mathrm{C}$ to $246 \mathrm{fF}$ at $31^{\circ} \mathrm{C}(n=$ $7, p=0.0351$, unpaired $t$ test). $C$, The $\mathrm{Ca}^{2+}$ influx during the first and second depolarizing pulses was $31.8 \pm 6.8 \mathrm{pC}$ and $31.7 \pm$ $6.8 \mathrm{pC}$ at room temperature $(n=4, p=0.93)$, whereas the $\mathrm{Ca}^{2+}$ influx during the first and second pulses was $62.8 \pm 3.8 \mathrm{pC}$ and $63.3 \pm 3.1 \mathrm{pC}$ at high temperature $(n=7, p=0.69)$. Both the first $(p=0.0005$, unpaired $t$ test) and the second $(p=0.0002$, unpaired $t$ test) pulses thus triggered more $\mathrm{Ca}^{2+}$ influx at high temperature. ${ }^{*} p<0.05,{ }^{* *} p<0.01,{ }^{* * *} p<0.001$.

\section{Discussion}

Temperature-dependent changes in EPSC, EPSP, and spike rates

Our in vitro whole-cell recordings of afferent fibers show that the frequencies of EPSCs and EPSPs increased at higher temperatures. This should produce an increase in AP spikes at higher temperatures. Indeed, afferent fiber spike rates mostly increased at higher temperatures (Fig. 1). In vivo single auditory nerve fiber recordings also show that spontaneous spike rates in the bullfrog amphibian papilla fibers increase at higher body temperatures (van Dijk et al., 1990). However, $\sim 30 \%$ of our recordings of afferent fibers decreased their spike rate at higher temperatures. We do not know the reasons for this heterogeneity. The underlying mechanisms that trigger spikes in the different afferent fibers require additional studies to explain the wide range of membrane input resistance (Fig. 4B). Interestingly, mammalian auditory nerve fibers also exhibit a heterogeneity in spike rates, gene ex- 

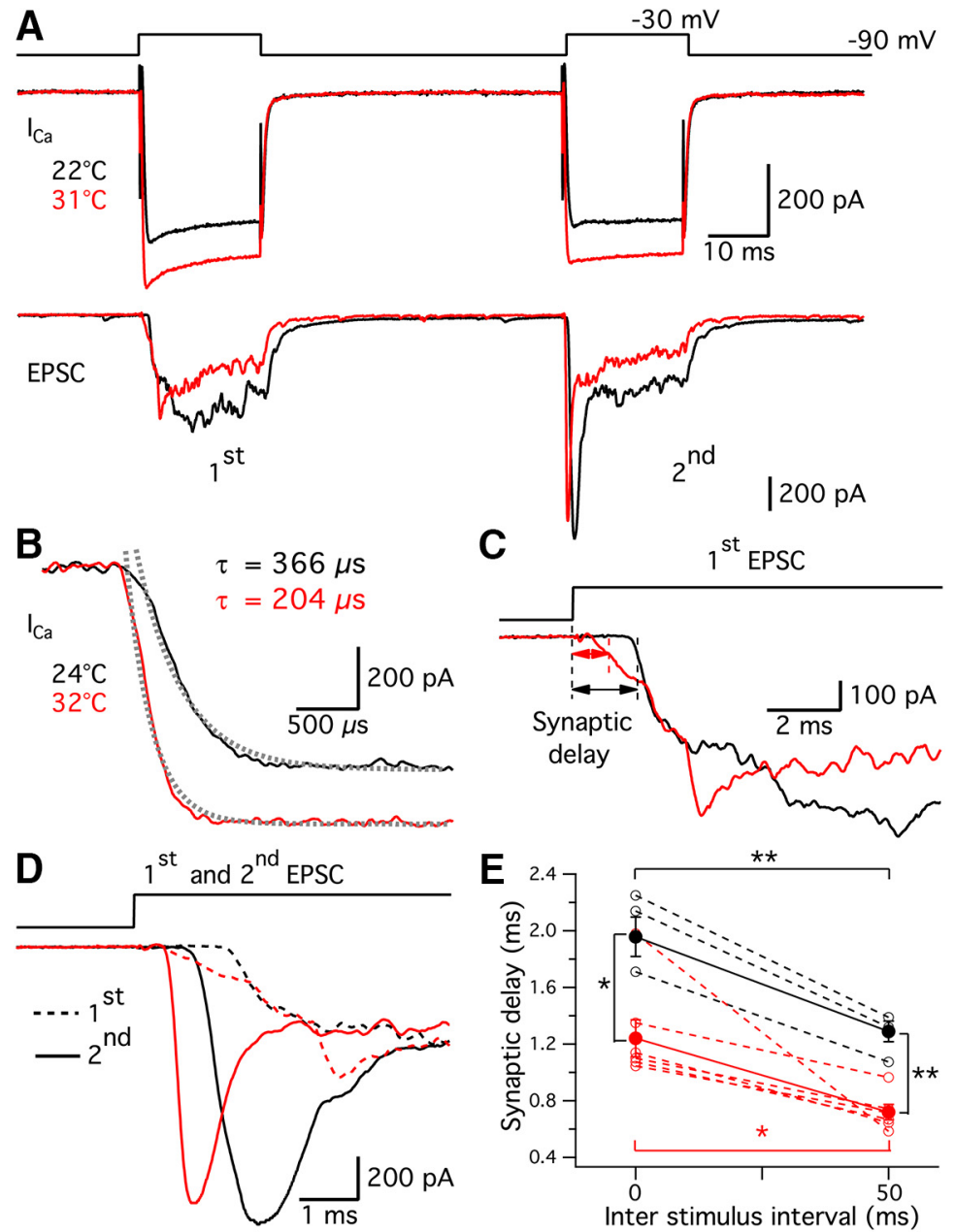

C
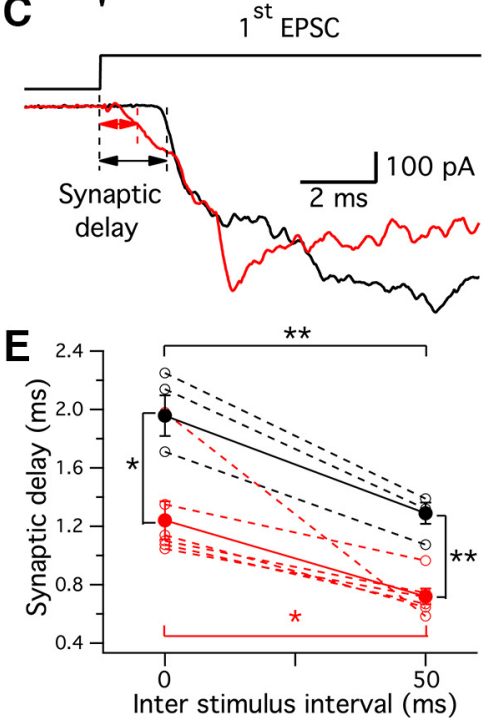

Figure 11. Shorter synaptic delays and faster EPSCs at high temperature. $\boldsymbol{A}$, Two $20 \mathrm{~ms}$ depolarizing steps from $-90 \mathrm{mV}$ to $-30 \mathrm{mV}$ with $50 \mathrm{~ms}$ intervals were applied to a hair cell. Simultaneously, the postsynaptic afferent fiber was voltage-clamped at $-90 \mathrm{mV}$. Average of calcium influx $\left(\mathrm{I}_{\mathrm{Ca}}\right)$ elicited by the hair cell stimulus at $22^{\circ} \mathrm{C}(n=3)$ and $31^{\circ} \mathrm{C}(n=6)$ are shown in black and red, respectively. Synaptic vesicle glutamate release from the hair cell triggered a multiquantal EPSC in the afferent fiber. Black and red traces represent the averaged EPSCs at $22^{\circ} \mathrm{C}(n=3)$ and $31^{\circ} \mathrm{C}(n=6)$, respectively. Due to significant rundown, we only analyzed the first trial of each pair. Therefore, $I_{c a}$ and EPSC responses at room and high temperature were obtained from two different groups of pairs. $\boldsymbol{B}$, Representative $\mathrm{Ca}^{2+}$ currents from another hair cell were triggered by a $20 \mathrm{~ms}$ depolarization from $-90 \mathrm{mV}$ to $-30 \mathrm{mV}$ at $24^{\circ} \mathrm{C}$ (black) and $32^{\circ} \mathrm{C}$ (red) using a P/4 protocol for leak subtraction. The activation time constant was derived from the single exponential fit after the capacitive transient (dashed lines). In this example, time constants of activation were $366 \mu \mathrm{s}$ at $24^{\circ} \mathrm{C}$ (black) and $204 \mu \mathrm{s}$ at $32^{\circ} \mathrm{C}$ (red). C, The rising phase of the first EPSC is shown on an expanded time scale. Synaptic delay was defined as the time between the start of stimulation and to when the EPSC reached $10 \%$ of the maximum. $D$ Overlay of the first (dashed lines) and the second (solid lines) EPSCs. Note the large synaptic facilitation of the second EPSCs. $\boldsymbol{E}$, The synaptic delay of both the first ( $p=0.0183$, unpaired $t$ test) and second EPSCS ( $p=0.001$, unpaired $t$ test) decreased at $31^{\circ} \mathrm{C}$. The first synaptic delay was longer than the second one under both $22^{\circ} \mathrm{C}(n=3, p=0.008)$ and $31^{\circ} \mathrm{C}(n=6, p=0.02) .{ }^{*} p<0.05$, ${ }^{* *} p<0.01$.

pression, and membrane properties (Rutherford et al., 2012; Heil and Peterson, 2017; Shrestha et al., 2018).

What are the mechanisms that produce an increase in EPSC frequency? One obvious possibility we explored was a depolarization of the hair cell $\mathrm{V}_{\text {rest }}$. Surprisingly, during whole-cell current-clamp recordings, the $\mathrm{V}_{\text {rest }}$ of hair cells hyperpolarized significantly (Fig. 5A). $\mathrm{V}_{\text {rest }}$ also hyperpolarizes in snail neurons at higher temperatures due to increased $\mathrm{Na}^{+} / \mathrm{K}^{+}$-ATPase activity (Gorman and Marmor, 1970). However, perforated patch recordings, which do not disturb the intracellular milieu, showed no significant change. The $\mathrm{V}_{\text {rest }}$ we observed in perforated patch mode was $\sim-63 \mathrm{mV}$ (Fig. $5 A$ ). Previous, sharp conventional electrode recordings of $\mathrm{V}_{\text {rest }}$ of turtle and frog hair cells reported values $\sim-55 \mathrm{mV}$ (Crawford and Fettiplace, 1980; Pitchford and
Ashmore, 1987). At these membrane potentials, a small inward $\mathrm{Ca}^{2+}$ current is induced (Fig. 5C). This resting $\mathrm{Ca}^{2+}$ current increases at higher temperatures, which probably increases release probability and spike rates (Trapani and Nicolson, 2011). The frequency of spontaneous mEPSCs also increases at high temperature at the calyx of Held synapse (Kushmerick et al., 2006; Postlethwaite et al., 2007) and hippocampal synapses (Kim and Connors, 2012). However, unlike bullfrog hair cells, $V_{\text {rest }}$ of the calyx of Held nerve terminal depolarizes when temperature increases from $24^{\circ} \mathrm{C}$ to $32^{\circ} \mathrm{C}$ (Kim and von Gersdorff, 2012). Finally, we note that our amphibian papilla hair cells are bathed in high external $\mathrm{Ca}^{2+}$, which blocks transduction channels; and recently, it was found that sudden heat rises can soften gating springs and open mechanotransduction channels on the stereocilia bundles of bullfrog sacculus hair cells (Azimzadeh et al., 2018). Therefore, we may be underestimating the physiological effects of temperature shifts on the hair cell, and $\mathrm{V}_{\text {rest }}$ may be more depolarized under in vivo conditions.

We found out that the average amplitude of the spontaneous EPSCs from bullfrog afferent fibers did not change at higher temperature (Fig. 2; Table 2). This differs from observations made in mammalian synapses where elevating temperature increases spontaneous mEPSC amplitude (Veruki et al., 2003; Kushmerick et al., 2006; Postlethwaite et al., 2007). Interestingly, we previously observed that a decrease in temperature from room temperature to $15^{\circ} \mathrm{C}$ resulted in a decrease in EPSC amplitude (Li et al., 2009). Spontaneous EPSC amplitudes may thus be saturated at room temperature. The average EPSP amplitude also did not change with temperature (Table 2). However, in 13 fibers where both EPSCs and EPSPs were recorded, EPSCs remained the same $(p=0.45)$, whereas EPSP amplitude decreased ( $p=0.049, n=13$ ) at high temperature. This could result from a decrease in afferent fiber $\mathrm{R}_{\text {in }}$ at high temperature. Both EPSC and EPSP events increased in frequency at high temperature (Table 2). This can lead to greater summation of EPSPs, making them more likely to reach AP threshold. However, EPSP decay was also significantly faster at higher temperatures (Fig. 2A3,B3), which tends to reduce summation of noncoincident EPSPs. Therefore, it is possible that higher temperatures may reduce spike rates, as shown in Figure $1 B$. Both presynaptic and postsynaptic mechanisms may thus explain the heterogeneity in spike frequency changes with temperature seen in Figure 1.

Temperature-dependent changes in spike threshold may also explain the heterogeneity shown in Figure 1. Thermo-positive fibers fire more spikes spontaneously at high temperature with 
threshold decreasing by $\sim 5 \mathrm{mV}$, whereas thermo-negative fibers fire less spontaneous spikes at high temperature with threshold increasing by $5 \mathrm{mV}$ (Table 1). Heterogeneity in the types and densities of voltage-gated $\mathrm{Na}^{+}$and $\mathrm{K}^{+}$channels among different fibers may explain these differences (Kim and Rutherford, 2016). Together, the temperature-dependent changes of spiking rates is due to presynaptic changes in hair cell exocytosis and postsynaptic changes in afferent fiber excitability.

\section{Synaptic delay and phase locking at high temperature}

Recordings of single frog auditory nerve fibers show that spike onset delay to sound stimulus decreased as temperature increased with $\mathrm{Q}_{10}$ values of 1.6-2.5 (Stiebler and Narins, 1990; van Dijk et al., 1990). We performed paired recordings from hair cell to afferent fiber and revealed a shortening of synaptic delay at high temperature (Fig. 11E). This shorter synaptic delay was due in part to a faster activation kinetics of $\mathrm{Ca}^{2+}$ current at high temperature (Fig. 11B). In addition, the time constant of lipid membrane fusion is inversely correlated to temperature (Schotten et al., 2015), which may also contribute to the shorter synaptic delay at high temperature. A shorter synaptic delay will improve the spike phase-locking of the fibers because evoked EPSPs and spikes will be more phase-locked to the hair cell $\mathrm{Ca}^{2+}$ current activation. This may explain why in vivo recordings from single auditory nerve fibers indicate that vector strength increases at higher temperatures (Stiebler and Narins, 1990; van Dijk et al., 1990).

Higher temperatures and synaptic facilitation tend to synchronize depolarization-evoked multivesicular release (Fig. 11). Synaptic facilitation revealed by paired-pulse depolarization also reduced synaptic delays in both bullfrog hair cell synapses (Cho et al., 2011) and rat inner hair cell synapses (synaptic delay was 1.5 $\mathrm{ms}$ at room temperature) (Goutman and Glowatzki, 2011). Likewise, we measured here synaptic delays of $1.3 \mathrm{~ms}$ at $23^{\circ} \mathrm{C}$ and 0.7 $\mathrm{ms}$ at $31^{\circ} \mathrm{C}$ (Fig. $\left.11 E\right)$.

\section{Electrical resonance at high temperature}

The lowering of $\mathrm{R}_{\text {in }}$ at high temperature reduces the membrane time constant, allowing hair cells to better follow rapid membrane potential changes (Fig. 6). The intrinsic electrical resonant frequency of hair cells increased with temperature (Fig. 7), as expected from an increase in $\mathrm{Ca}^{2+}$ and $\mathrm{K}^{+}$current amplitudes (Fig. $5 B$ ). We observed a large change in average resonant frequency from 320 to $530 \mathrm{~Hz}$ (Fig. 7D). These changes increase the dynamic range of frequency tuning of amphibian papilla hair cells and their connected afferent fibers. Indeed, in vivo recordings of frog auditory nerve fibers show higher characteristic frequencies (tuning curve tip or best frequency) at higher temperature (Stiebler and Narins, 1990).

Exocytosis efficiency and vesicle pool size at high temperature Smaller $\mathrm{R}_{\text {in }}$ will inevitably result in smaller membrane potential changes $\left(\mathrm{V}_{\mathrm{m}}=\mathrm{R}_{\mathrm{in}} \times \mathrm{I}\right)$ induced by the opening of mechanosensitive channels in the stereocilia. This predicted loss of sensitivity to sound signals is not observed in vivo. Indeed, the contrary is observed: the threshold for sound triggered spikes is reduced at high temperature (Stiebler and Narins, 1990). How can we explain this increase in fiber sensitivity?

First, we found that the steepness of the $\mathrm{Ca}^{2+}$ current $I-V$ curve (Fig. 5C) increased at high temperature making $\mathrm{Ca}^{2+}$ influx more sensitive to membrane potential fluctuations around $\mathrm{V}_{\text {rest }}$. The enlarged $\mathrm{Ca}^{2+}$ current could result from an increase in L-type $\mathrm{Ca}^{2+}$ channel open probability $\left(\mathrm{P}_{\mathrm{o}}\right)$ and/or conductance
(Lux and Brown, 1984; Klöckner et al., 1990; Acerbo and Nobile, 1994; Peloquin et al., 2008). The $\mathrm{Q}_{10}$ of single L-type channel conductance in smooth muscle cells and retina is 1.6 and 3.0, respectively (Klöckner et al., 1990; Peloquin et al., 2008). Second, at hair cell synapses, a cluster of L-type $\mathrm{Ca}^{2+}$ channels is located within nanometers from docked vesicles under the synaptic ribbon (Brandt et al., 2005; Nouvian et al., 2006; Graydon et al., 2011; Kim et al., 2013). Fast activation of this cluster of $\mathrm{Ca}^{2+}$ channels produces a highly synchronous and fast multiquantal EPSC (Fig. 11D) (Grabner et al., 2016), which may help to explain the short latency and low jitter of the sound evoked first-spike in the auditory nerve (Wittig and Parsons, 2008).

We also observed an increase in exocytosis efficiency, which indicates the exocytosis increase is not proportional to the increase of $\mathrm{Ca}^{2+}$ current. A nonlinear power law dependence of exocytosis on free $\mathrm{Ca}^{2+}$ ion concentration could potentially explain our results of a high $\mathrm{Q}_{10}=2.4$ for exocytosis elicited by 20 ms depolarizing pulses (Cho and von Gersdorff, 2012; Quiñones et al., 2012). However, a linear dependence of exocytosis on $\mathrm{Ca}^{2+}$ current charge has been found for mid-frequency tuned bullfrog hair cells (Keen and Hudspeth, 2006; Cho et al., 2011). Thus, vesicle fusion efficiency must be intrinsically higher at high temperature, as shown in Figure $9 \mathrm{C}$. In addition to $\mathrm{Ca}^{2+}$ influx through L-type $\mathrm{Ca}^{2+}$ channels in the plasma membrane, $\mathrm{Ca}^{2+}$ induced $\mathrm{Ca}^{2+}$ release from intracellular stores can also be involved in nonlinear vesicle recruitment at auditory hair cells (Castellano-Muñoz et al., 2016).

Release probability increases at high temperature for some central synapses (Hardingham and Larkman, 1998; Volgushev et al., 2004), although we did not observe changes in release probability using a paired-pulse stimulation protocol (Figs. 10, 11). However, we did observe a significant increase in the RRP size at high temperature (Fig. 10). In addition to facilitating spontaneous vesicle fusion, temperature also facilitates sustained exocytosis by accelerating vesicle replenishment of the RRP (Pyott and Rosenmund, 2002; Kushmerick et al., 2006). Moreover, synaptic vesicle endocytosis is also highly temperature-sensitive (FernándezAlfonso and Ryan, 2004; Micheva and Smith, 2005; Renden and von Gersdorff, 2007; Delvendahl et al., 2016). The kinetics of endocytosis may thus be rate limiting for prolonged exocytosis and requires further studies at hair cell synapses.

\section{References}

Acerbo P, Nobile M (1994) Temperature dependence of multiple high voltage activated $\mathrm{Ca}^{2+}$ channels in chick sensory neurones. Eur Biophys J 23:189-195.

Art JJ, Fettiplace R (1987) Variation of membrane properties in hair cells isolated from the turtle cochlea. J Physiol 385:207-242.

Auger C, Attwell D (2000) Fast removal of synaptic glutamate by postsynaptic transporters. Neuron 28:547-558.

Azimzadeh JB, Fabella BA, Kastan NR, Hudspeth AJ (2018) Thermal excitation of the mechanotransduction apparatus of hair cells. Neuron 97: 586-595.e4.

Brandt A, Khimich D, Moser T (2005) Few $\mathrm{Ca}_{\mathrm{V}} 1.3$ channels regulate the exocytosis of a synaptic vesicle at the hair cell ribbon synapse. J Neurosci 25:11577-11585.

Breneman KD, Highstein SM, Boyle RD, Rabbitt RD (2009) The passive cable properties of hair cell stereocilia and their contribution to somatic capacitance measurements. Biophys J 96:1-8.

Brown TH, Fricke RA, Perkel DH (1981) Passive electrical constants in three classes of hippocampal neurons. J Neurophysiol 4:812-827.

Capranica RR (1965) The evoked vocal response of the bullfrog: a study of communication by sound (Monograph 33). Cambridge, MA: Massachusetts Institute of Technology.

Castellano-Muñoz M, Schnee ME, Ricci AJ (2016) Calcium-induced cal- 
cium release supports recruitment of synaptic vesicles in auditory hair cells. J Neurophysiol 115:226-239.

Ceballos CC, Roque AC, Leão RM (2017) The role of negative conductances in neuronal subthreshold properties and synaptic integration. Biophys Rev 9:827-834.

Cho S, von Gersdorff $\mathrm{H}$ (2012) $\mathrm{Ca}^{2+}$ influx and neurotransmitter release at ribbon synapses. Cell Calcium 52:208-216.

Cho S, Li GL, von Gersdorff H (2011) Recovery from short-term depression and facilitation is ultrafast and $\mathrm{Ca}^{2+}$ dependent at auditory hair cell synapses. J Neurosci 31:5682-5692.

Coate TM, Scott MK, Gurjar M (2019) Current concepts in cochlear ribbon synapse formation. Synapse 73:e22087.

Crawford AC, Fettiplace R (1980) The frequency selectivity of auditory nerve fibers and hair cells in the cochlea of the turtle. J Physiol 306: $79-125$.

Crawford AC, Fettiplace R (1981) An electrical tuning mechanism in turtle cochlear hair cells. J Physiol 312:377-412.

Delvendahl I, Vyleta NP, von Gersdorff H, Hallermann S (2016) Fast, temperature-sensitive and clathrin-independent endocytosis at central synapses. Neuron 90:492-498.

Dinkelacker V, Voets T, Neher E, Moser T (2000) The readily releasable pool of vesicles in chromaffin cells is replenished in a temperaturedependent manner and transiently overfills at $37^{\circ} \mathrm{C}$. J Neurosci 20:83778383.

Ellis KJ, Morrison JF (1982) Buffers of constant ionic strength for studying pH-dependent processes. Methods Enzymol 87:405-426.

Emlen ST (1968) Territoriality in the bullfrog, Rana catesbeiana. Copeia 1968:240-243.

Engel J (2008) Gerbils can tune in. J Physiol 586:919.

Fatt P, Katz B (1952) Spontaneous subthreshold activity at motor nerve endings. J Physiol 117:109-128.

Feng AS, Narins PM, Capranica RR (1975) Three populations of primary auditory fibers in the bullfrog (Rana catesbeiana): their peripheral origins and frequency sensitivities. J Comp Physiol 100:221-229.

Fernández-Alfonso T, Ryan TA (2004) The kinetics of synaptic vesicle pool depletion at CNS synaptic terminals. Neuron 41:943-953.

Frank T, Khimich D, Neef A, Moser T (2009) Mechanisms contributing to synaptic $\mathrm{Ca}^{2+}$ signals and their heterogeneity in hair cells. Proc Natl Acad Sci U S A 106:4483-4488

Frolov D, Li GL (2017) Probing electrical tuning of hair cells with a zap current method in the intact amphibian papilla of bullfrogs. Synapse $71: \mathrm{e} 21942$.

Gillis KD (2000) Admittance-based measurement of membrane capacitance using the EPC-9 patch-clamp amplifier. Pflugers Arch 439:655664.

Gillis KD, Mossner R, Neher E (1996) Protein kinase C enhances exocytosis from chromaffin cells by increasing the size of the readily releasable pool of secretory granules. Neuron 16:1209-1220.

Golowasch J, Thomas G, Taylor AL, Patel A, Pineda A, Khalil C, Nadim F (2009) Membrane capacitance measurements revisited: dependence of capacitance value on measurement method in nonisopotential neurons. J Neurophysiol 102:2161-2175.

Gorman AL, Marmor MF (1970) Contributions of the sodium pump and ionic gradients to the membrane potential of a molluscan neurone. J Physiol 210:897-917.

Goutman JD, Glowatzki E (2011) Short-term facilitation modulates size and timing of the synaptic response at the inner hair cell ribbon synapse. J Neurosci 31:7974-7981.

Grabner CP, Ratliff CP, Light AC, DeVries SH (2016) Mechanism of highfrequency signaling at a depressing ribbon synapse. Neuron 91:133-145.

Grant L, Yi E, Glowatzki E (2010) Two modes of release shape the postsynaptic response at the inner hair cell ribbon synapse. J Neurosci 30:42104220.

Graydon CW, Cho S, Li GL, Kachar B, von Gersdorff H (2011) Sharp Ca ${ }^{2+}$ nanodomains beneath the ribbon promote highly synchronous multivesicular release at hair cell synapses. J Neurosci 31:16637-16650.

Graydon CW, Cho S, Diamond JS, Kachar B, von Gersdorff H, Grimes WN (2014) Specialized postsynaptic morphology enhances neurotransmitter dilution and high-frequency signaling at an auditory synapse. J Neurosci 34:8358-8372.

Hardingham NR, Larkman AU (1998) The reliability of excitatory synaptic transmission in slices of rat visual cortex in vitro is temperature dependent. J Physiol 507:249-256.

Heffner HE, Heffner RS (2007) Hearing ranges of laboratory animals. J Am Assoc Lab Animal Sci 46:20-22.

Heil P, Peterson AJ (2017) Spike timing in auditory-nerve fibers during spontaneous activity and phase locking. Synapse 71:5-36.

Hudspeth AJ, Lewis RS (1988) Kinetic analysis of voltage- and iondependent conductances in saccular hair cells of the bull-frog, Rana catesbeiana. J Physiol 400:237-274.

Johnson HA (1987) Thermal noise and biological information. Q Rev Biol 62:141-152.

Johnson SL, Marcotti W (2008) Biophysical properties of Cav1.3 calcium channels in gerbil inner hair cells. J Physiol 586:1029-1042.

Johnson SL, Olt J, Cho S, von Gersdorff H, Marcotti W (2017) The coupling between $\mathrm{Ca}^{2+}$ channels and the exocytotic $\mathrm{Ca}^{2+}$ sensor at hair cell ribbon synapses varies tonotopically along the mature cochlea. J Neurosci 37 : 2471-2484.

Keen EC, Hudspeth AJ (2006) Transfer characteristics of the hair cell's afferent synapse. Proc Natl Acad Sci U S A 103:5537-5542.

Kim JA, Connors BW (2012) High temperatures alter physiological properties of pyramidal cells and inhibitory interneurons in hippocampus. Front Cell Neurosci 6:27.

Kim JH, von Gersdorff H (2012) Suppression of spikes during posttetanic hyperpolarization in auditory neurons: the role of temperature, $\mathrm{I}(\mathrm{h})$ currents, and the $\mathrm{Na}^{+}-\mathrm{K}^{+}$-ATPase pump. J Neurophysiol 108:1924-1932.

Kim KX, Rutherford MA (2016) Maturation of $\mathrm{Na}_{\mathrm{V}}$ and $\mathrm{K}_{\mathrm{V}}$ channel topographies in the auditory nerve spike initiator before and after developmental onset of hearing function. J Neurosci 36:2111-2118.

Kim MH, Li GL, von Gersdorff H (2013) Single $\mathrm{Ca}^{2+}$ channels and exocytosis at sensory synapses. J Physiol 591:3167-3178.

Klöckner U, Schiefer A, Isenberg G (1990) L-type Ca-channels: similar $Q_{10}$ of Ca-, Ba- and Na-conductance points to the importance of ion-channel interaction. Pflugers Arch 415:638-641.

Kushmerick C, Renden R, von Gersdorff H (2006) Physiological temperatures reduce the rate of vesicle pool depletion and short-term depression via an acceleration of vesicle recruitment. J Neurosci 26:1366-1377.

Lewis ER, Li CW (1975) Hair cell types and distributions in the otolithic and auditory organs of the bullfrog. Brain Res 83:35-50.

Li GL, Keen E, Andor-Ardó D, Hudspeth AJ, von Gersdorff H (2009) The unitary event underlying multiquantal EPSCs at a hair cell's ribbon synapse. J Neurosci 29:7558-7568.

Li GL, Cho S, von Gersdorff H (2014) Phase-locking precision is enhanced by multiquantal release at an auditory hair cell ribbon synapse. Neuron 83:1404-1417.

Liberman MC (1980) Morphological differences among radial afferent fibers in the cat cochlea: an electron-microscopic study of serial sections. Hear Res 3:45-63.

Lillywhite HB (1970) Behavioral temperature regulation in the bullfrog, Rana catesbeiana. Copeia 1970:158-168.

Lindau M, Neher E (1988) Patch-clamp techniques for time-resolved capacitance measurements in single cells. Pflugers Arch 411:137-146.

Lux HD, Brown AM (1984) Patch and whole cell calcium currents recorded simultaneously in snail neurons. J Gen Physiol 83:727-750.

Michalski N, Goutman JD, Auclair SM, Boutet de Monvel J, Tertrais M, Emptoz A, Parrin A, Nouaille S, Guillon M, Sachse M, Ciric D, Bahloul A, Hardelin JP, Sutton RB, Avan P, Krishnakumar SS, Rothman JE, Dulon D, Safieddine S, Petit C (2017) Otoferlin acts as a $\mathrm{Ca}^{2+}$ sensor for vesicle fusion and vesicle pool replenishment at auditory hair cell ribbon synapses. eLife 6:e31013.

Micheva KD, Smith SJ (2005) Strong effects of subphysiological temperature on the function and plasticity of mammalian presynaptic terminals. J Neurosci 25:7481-7488.

Moser T, Beutner D (2000) Kinetics of exocytosis and endocytosis at the cochlear inner hair cell afferent synapse of the mouse. Proc Natl Acad Sci U S A 97:883-888.

Mostafavi H, Thiyagarajan S, Stratton BS, Karatekin E, Warner JM, Rothman JE, O'Shaughnessy B (2017) Entropic forces drive self-organization and membrane fusion by SNARE proteins. Proc Natl Acad Sci U S A 114: $5455-5460$

Nouvian R (2007) Temperature enhances exocytosis efficiency at the mouse inner hair cell ribbon synapse. J Physiol 584:535-542. 
Nouvian R, Beutner D, Parsons TD, Moser T (2006) Structure and function of the hair cell ribbon synapse. J Membr Biol 209:153-165.

Pangrsic T, Singer JH, Koschak A (2018) Voltage-gated calcium channels: key players in sensory coding in the retina and the inner ear. Physiol Rev 98:2063-2096.

Peloquin JB, Doering CJ, Rehak R, McRory JE (2008) Temperature dependence of Cav1.4 calcium channel gating. Neuroscience 151:1066-1083.

Pitchford S, Ashmore JF (1987) An electrical resonance in hair cells of the amphibian papilla of the frog Rana temporaria. Hear Res 27:75-83.

Postlethwaite M, Hennig MH, Steinert JR, Graham BP, Forsythe ID (2007) Acceleration of AMPA receptor kinetics underlies temperaturedependent changes in synaptic strength at the rat calyx of held. J Physiol 579:69-84

Pyott SJ, Rosenmund C (2002) The effects of temperature on vesicular supply and release in autaptic cultures of rat and mouse hippocampal neurons. J Physiol 539:523-535.

Quiñones PM, Luu C, Schweizer FE, Narins PM (2012) Exocytosis in the frog amphibian papilla. J Assoc Res Otolaryngol 13:39-54.

Rall W (1969) Time constants and electrotonic length of membrane cylinders and neurons. Biophys J 9:1483-1508.

Renden R, von Gersdorff H (2007) Synaptic vesicle endocytosis at a CNS nerve terminal: faster kinetics at physiological temperatures and increased endocytotic capacity during maturation. J Neurophysiol 98:3349-3359.

Rutherford MA (2015) Resolving the structure of the inner ear ribbon synapses with STED microscopy. Synapse 69:242-255.

Rutherford MA, Chapochnikov NM, Moser T (2012) Spike encoding of neurotransmitter release timing by spiral ganglion neurons of the cochlea. J Neurosci 32:4773-4789.

Santin JM, Watters KC, Putnam RW, Hartzler LK (2013) Temperature influences neuronal activity and $\mathrm{CO}_{2} / \mathrm{pH}$ sensitivity of locus coeruleus neurons in the bullfrog, Lithobates catesbeianus. Am J Physiol Regul Integr Comp Physiol 305:R1451-R1464.

Schnee ME, Castellano-Muñoz M, Ricci AJ (2013) Response properties from turtle auditory hair cell afferent fibers suggest spike generation is driven by synchronized release both between and within synapses. J Neurophysiol 110:204-220.

Schotten S, Meijer M, Walter AM, Huson V, Mamer L, Kalogreades L, ter Veer M, Ruiter M, Brose N, Rosenmund C, Sørensen JB, Verhage M, Cornelisse LN (2015) Additive effects on the energy barrier for synaptic vesicle fusion cause supralinear effects on the vesicle fusion rate. Elife 4:e05531.

Shrestha BR, Chia C, Wu L, Kujawa SG, Liberman MC, Goodrich LV (2018) Sensory neuron diversity in the inner ear is shaped by activity. Cell 174:1229-1246.e17.

Simmons AM (2004) Call recognition in the bullfrog, Rana catesbeiana: generalization along the duration continuum. J Acoust Soc Am 115: $1345-1355$.
Smotherman MS, Narins PM (1998) Effect of temperature on electrical resonance in leopard frog saccular hair cells. J Neurophysiol 79:312-321.

Smotherman MS, Narins PM (1999) The electrical properties of auditory hair cells in the frog amphibian papilla. J Neurosci 19:5275-5292.

Smotherman MS, Narins PM (2000) Hair cells, hearing and hopping: a field guide to hair cell physiology in the frog. J Exp Biol 203:2237-2246.

Stiebler IB, Narins PM (1990) Temperature dependence of auditory nerve response properties in the frog. Hear Res 46:63-81.

Trapani JG, Nicolson T (2011) Mechanism of spontaneous activity in afferent neurons of the zebrafish lateral-line organ. J Neurosci 31:1614-1623.

Tsien RY (1980) New calcium indicators and buffers with high selectivity against magnesium and protons: design, synthesis, and properties of prototype structures. Biochemistry 19:2396-2404.

van Dijk P, Lewis ER, Wit HP (1990) Temperature effects on auditory nerve fiber response in the American bullfrog. Hear Res 44:231-240.

van Dijk P, Mason MJ, Schoffelen RL, Narins PM, Meenderink SW (2011) Mechanics of the frog ear. Hear Res 273:46-58.

Veruki ML, Mørkve SH, Hartveit E (2003) Functional properties of spontaneous EPSCs and non-NMDA receptors in rod amacrine (AII) cells in the rat retina. J Physiol 549:759-774.

Volgushev M, Kudryashov I, Chistiakova M, Mukovski M, Niesmann J, Eysel UT (2004) Probability of transmitter release at neocortical synapses at different temperatures. J Neurophysiol 92:212-220.

Wiewandt TA (1969) Vocalization, aggressive behavior, and territoriality in the bullfrog, Rana catesbeiana. Copeia 1969:276-285.

Wittig JH Jr, Parsons TD (2008) Synaptic ribbon enables temporal precision of hair cell afferent synapse by increasing the number of readily releasable vesicles: a modeling study. J Neurophysiol 100:1724-1739.

Wu JS, Young ED, Glowatzki E (2016) Maturation of spontaneous firing properties after hearing onset in rat auditory nerve fibers: spontaneous rates, refractoriness, and interfiber correlations. J Neurosci 36:10584-10597.

Wu LG, Borst JG (1999) The reduced release probability of releasable vesicles during recovery from short-term synaptic depression. Neuron 23: 821-832.

Yang XF, Ouyang Y, Kennedy BR, Rothman SM (2005) Cooling blocks rat hippocampal neurotransmission by a presynaptic mechanism: observations using 2-photon microscopy. J Physiol 567:215-224.

Yang Y, Ramamurthy B, Neef A, Xu-Friedman MA (2016) Low somatic sodium conductance enhances action potential precision in time-coding auditory neurons. J Neurosci 36:11999-12009.

Yi E, Roux I, Glowatzki E (2010) Dendritic HCN channels shape excitatory postsynaptic potentials at the inner hair cell afferent synapse in the mammalian cochlea. J Neurophysiol 103:2532-2543.

Zhang Z, Jackson MB (2008) Temperature dependence of fusion kinetics and fusion pores in $\mathrm{Ca}^{2+}$-triggered exocytosis from PC12 cells. J Gen Physiol 131:117-124. 